\title{
Potential climate change impacts on the water balance of regional unconfined aquifer systems in south-western Australia
}

\author{
R. Ali ${ }^{1}$, D. McFarlane ${ }^{1}$, S. Varma ${ }^{2}$, W. Dawes ${ }^{1}$, I. Emelyanova ${ }^{1}$, and G. Hodgson ${ }^{1}$ \\ ${ }^{1}$ CSIRO Floreat Laboratories, Private Bag 5, Wembley, 6913, Western Australia \\ ${ }^{2}$ CSIRO Earth Science and Resource Engineering, 26 Dick Parry Avenue, Kensington WA 6151, Australia
}

Correspondence to: R. Ali (riasat.ali@csiro.au)

Received: 26 April 2012 - Published in Hydrol. Earth Syst. Sci. Discuss.: 24 May 2012

Revised: 16 November 2012 - Accepted: 16 November 2012 - Published: 4 December 2012

\begin{abstract}
This study assesses climate change impacts on water balance components of the regional unconfined aquifer systems in south-western Australia, an area that has experienced a marked decline in rainfall since the mid 1970s and is expected to experience further decline due to global warming. Compared with the historical period of 1975 to 2007 , reductions in the mean annual rainfall of between 15 and 18 percent are expected under a dry variant of the 2030 climate which will reduce recharge rates by between 33 and 49 percent relative to that under the historical period climate. Relative to the historical climate, reductions of up to 50 percent in groundwater discharge to the ocean and drainage systems are also expected. Sea-water intrusion is likely in the PeelHarvey Area under the dry future climate and net leakage to confined systems is projected to decrease by up to 35 percent which will cause reduction in pressures in confined systems under current abstraction. The percentage of net annual recharge consumed by groundwater storage, and ocean and drainage discharges is expected to decrease and percentage of net annual recharge consumed by pumping and net leakage to confined systems to increase under median and dry future climates. Climate change is likely to significantly impact various water balance components of the regional unconfined aquifer systems of south-western Australia. We assess the quantitative climate change impact on the different components (the amounts) using the most widely used GCMs in combination with dynamically linked recharge and physically distributed groundwater models.
\end{abstract}

\section{Introduction}

Climate change affects temperature, rainfall and relative humidity and has a flow-on effect throughout the hydrological cycle (Loáiciga et al., 1996). There is evidence of a temperature increase of $0.74{ }^{\circ} \mathrm{C}$ in the average surface temperature of the earth during the 20th century (IPPC, 2007; UNEP, 2007) and a further increase of 1.4 to $5.8^{\circ} \mathrm{C}$ by 2100 is projected due to greenhouse gas emissions (McCarthy et al., 2001). The climate change has impacted rainfall in many parts of the world (Ducci and Tranfaglia, 2008) and has caused significant reductions in a number of regions impacting on the availability of both surface and groundwater resources. There is evidence of decline in summer and autumn precipitation in drier northeastern regions of China since 1960 (Piao et al., 2010) and decline in mean annual rainfall in the southwest Western Australia and parts of the southern and eastern Australia during the second half of the 20th century (PMSEIC Independent Working Group, 2007). Climate change is likely to further impact rainfall in the future in many regions of the world and in some parts precipitation is projected to increase (w.g. van Roosmalen, 2007, 2009). Increasing or decreasing precipitation and the resulting increase or decrease in groundwater recharge or discharge may also deteriorate dependent or associated ecosystems and agricultural production (Aldous et al., 2011; Barron et al., 2012; Hinsby et al., 2012; Jeppesen et al., 2009; Olesen et al., 2007; Sonnenborg et al., 2012).

Global climate models (GCM) are used for projecting future climates. Recent advances in modelling and improved understanding of the physical processes of climate systems have made projections of future climate more reliable 
(Christensen et al., 2007; Pirani, 2011; Taylor et al., 2012) and simulation results from downscaled global circulation models have been used for regional studies of the impact on the hydrological cycle by integrated hydrological models (e.g. van Roosmalen et al., 2007, 2009; Goderniaux et al., 2009, 2011) including water quality issues (Sonnenborg et al., 2012).

Both the temperature rise and rainfall decline due to climate change affects various components of the groundwater balance by directly and indirectly affecting multiple factors (Zagonari, 2010) such as groundwater recharge (Ng et al., 2010) due to rainfall decline, potential evapotranspiration due to temperature and vapour pressure deficits rise, and groundwater discharge to drains due to groundwater levels decline. It can increase seawater intrusion risks in coastal aquifers and affect inter-aquifer leakage rates and flow direction. Although the research on climate change effects on groundwater systems is relatively scarce (Marshall and Randhir, 2007) it is rapidly increasing (Barthel et al., 2011; van Roosmalen et al., 2007, 2009; Goderniaux et al., 2011; Sonnenborg et al., 2012). Some studies have either fully or partly addressed the effects of recent past and projected climate change on groundwater resources using various hydrological, regression, modelling and isotope techniques (Scibek and Allen, 2006; Isaar, 2008; Ducci and Tranfaglia, 2008; Polemio and Casarano, 2009; Sinha and Navada, 2008). Only few studies have applied truly integrated hydrological models that are physically-based and spatially distributed both on the surface and in the subsurface (Goderniaux et al., 2009). Often variable results are produced (Jiang et al., 2007) due to simplistic assumptions made in climate projections and representation of physical processes of the hydrological system.

A reliable estimate of recharge is the first requirement in estimating the impact of climate change on groundwater systems because it represents the connection between atmospheric, surface and sub-surface processes and is impacted by many factors including changed precipitation and temperature regimes, coastal flooding, urbanisation and surface sealing, woodland creation and rotation changes (Holman, 2006). Various simple water balance techniques and models are available to estimate recharge (Aguilera and Murillo, 2009; Barr et al., 2003; Herrera-Pontoja and Hiscock, 2008; Sanford, 2002). It can be used as input to numerical groundwater models which distribute this recharge into various components of the water balance, or a recharge model can be dynamically linked with the groundwater models which estimate recharge at each stress period depending on variations in climate and land surface conditions.

Input from recharge models can be used in groundwater models to study the impacts of climate change on groundwater systems. Scibek and Allen (2006) and Woldeamlak et al. (2007) used physically-based distributed recharge models to estimate annual recharge and used this in MODFLOW model to simulate groundwater in Grand Forks in south central British Columbia and in Grote-N Belgium, respectively.
Various recharge and groundwater models have been used in Australia to study the impacts of climate change on future groundwater resource availability in the Murray-Darling Basin, Northern Australia, Tasmania and south-west Western Australia (Ali et al., 2010, 2012; Crosbie et al., 2010; CSIRO, 2008, 2009; Post et al., 2011).

Most studies used recharge as a direct input in groundwater models. Our study dynamically linked a recharge model that takes account of variations in climate, land surface condition and groundwater depth with MODFLOW based groundwater models. By dynamically linking a recharge model with a groundwater model the effect of depth to water table on recharge was also taken into account. Quantification of storage change and discharge changes by simultaneously considering unsaturated and saturated processed based models is an important step forward in this field of study.

The main objectives of this study were to dynamically link a recharge model with MODFLOW based groundwater models and simulate the potential climate change impacts on the water balance of the coastal plain unconfined aquifers of south-western Australia.

\section{Description of study area}

The study area is located between Gingin to the north and Augusta to the south of Perth (Fig. 1). For this study the area was divided into three parts: the Central Perth Basin, the Peel-Harvey Area and the Southern Perth Basin, all of which are part of the Perth Basin (Fig. 1). The study area covers about $20000 \mathrm{~km}^{2}$ and is located in one of the highest rainfall parts of south-western Australia. It includes all fresh, brackish and marginal groundwater resources near the coast. Inland groundwater supplies are either limited or too saline for most domestic, irrigation and industrial uses and were therefore excluded from this assessment. The study area has over 80 percent of Western Australia's population and accounts for over half of the horticultural production of the state (van Gool and Runge, 1999).

Groundwater is a major source of water in the study area. The Perth Basin comprises the flat sandy Swan and Scott coastal plains, and more elevated and clayey plateaux such as the Blackwood in the Southern Perth Basin and Dandaragan in the Central Perth Basin (Fig. 1).

\subsection{Climate}

The study area has a Mediterranean type climate, with mean annual rainfall of between 500 and $1200 \mathrm{~mm}$, up to 80 percent of which occurs between May and October. Temperatures are also at their lowest during this period, making the rainfall more effective in terms of producing runoff and recharge. There is a strong south-west to north-east gradient in rainfall (Fig. 2) with the highest rainfall in south-west coastal parts and along the Darling Range east of the Darling 


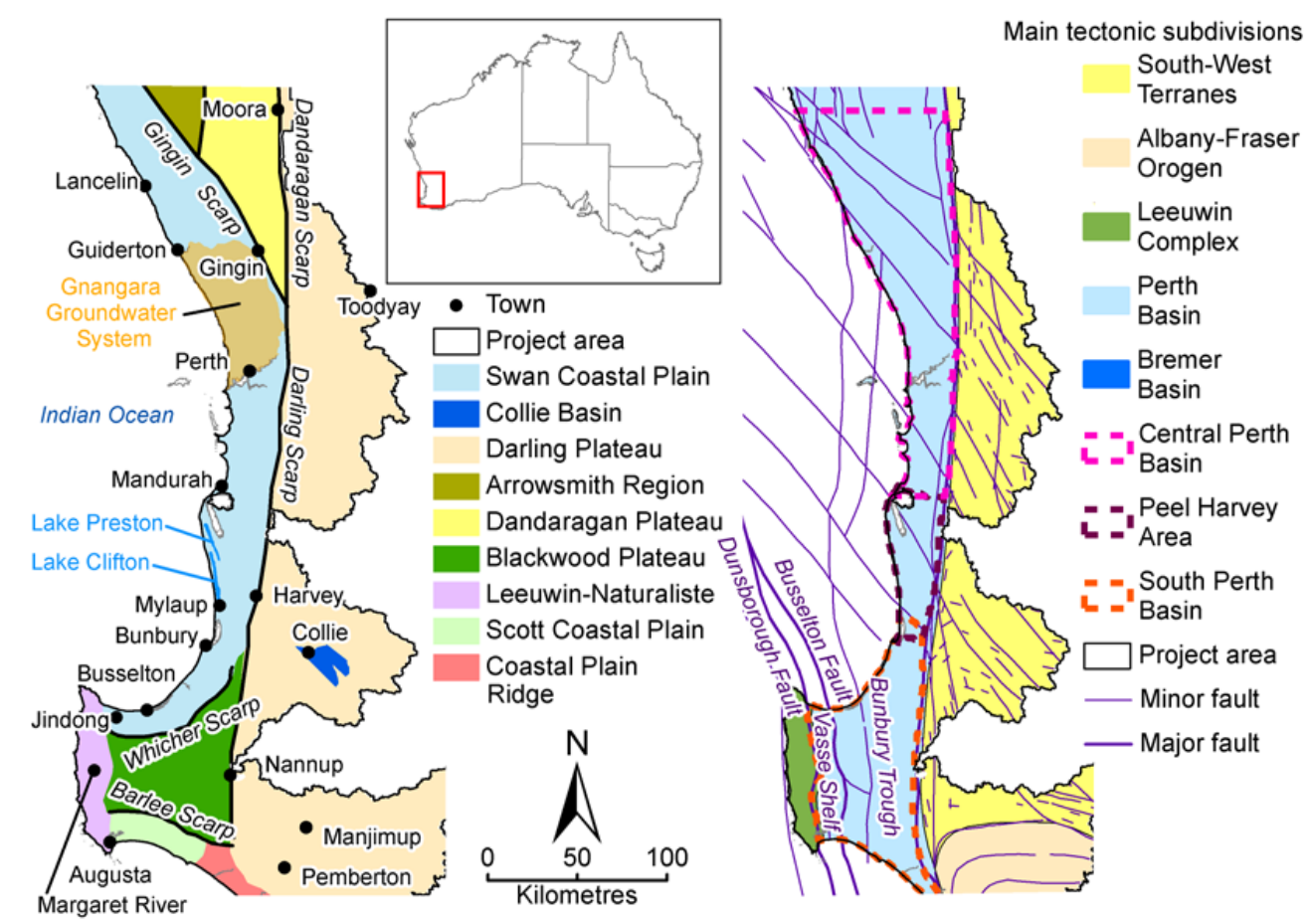

Fig. 1. Map of the study area and main tectonic subdivisions.

Scarp. The mean annual areal potential evapotranspiration (APET; Morton, 1983) varies from $1555 \mathrm{~mm}$ in the north to $1260 \mathrm{~mm}$ in the south. When mean annual rainfall deficit is calculated by subtracting APET from rainfall, almost all of the study area has a negative moisture balance.

\subsection{Land cover}

Major land covers in the study area include dryland agriculture, native vegetation, pine plantation and urban (Fig. 3). Over 88 percent of the study area is covered by either native vegetation (45 percent) or dryland agriculture (43 percent). Pine plantations cover 2 percent of the area. Horticulture, valued at $\$ 166$ million annually covers less than 1 percent of the study area but makes up 33 percent of total agricultural production (van Gool and Runge, 1999). Intensive urban and commercial buildings cover about 6 percent of the study area and occur in the Perth region and, to a lesser extent, around Bunbury and Busselton.

The main areas under native vegetation occur east of the Darling Fault in the Darling Ranges, along the South Coast and north of Perth. Pine plantations occur in the Gnangara area north of Perth, near Myalup east of Lake Clifton and on the Blackwood Plateau. Cleared areas used for dryland cropping and grazing mainly occur on the Swan Coastal Plain. Irrigated areas occur in the Harvey and Preston areas (Fig. 3). Self-supplied horticultural areas, i.e. using water extracted from farmer-owned wells or dams, occur around Gingin, in peri-urban parts of Perth, and in south-western coastal areas at Myalup, Jindong and Margaret River.

\subsection{Hydrogeology}

The Central Perth Basin extends $150 \mathrm{~km}$ north and $70 \mathrm{~km}$ south of Perth and comprises the Swan Coastal Plain and southern Dandaragan Plateau. The three main aquifers are the Superficial, Leederville and Yarragadee. Locally important aquifers include the Parmelia, Rockingham, Mirrabooka and Poison Hill aquifers (Fig. 4). The lithology and hydraulic conductivity of geological units are listed in Table 1 . The sub-surface geology and sub-cropping strata for the Central Perth Basin (Fig. 4a) show the degree of connectivity with underlying aquifers such as the Leederville Aquifer. The unconfined Superficial Aquifer is mainly clayey (Guildford Formation) in the east near Gingin Scarp and contains various sandy formations such as Safety Bay Sand, Becker Sand and Tamala Limestone towards the Indian Ocean in the west. Its average thickness is about $30 \mathrm{~m}$. The Pinjar, Wanneroo and Mariginiup members of the Leederville Formation directly underlie the superficial formations in the northeast and south and the Osborne Formation in the middle (Fig. 4b). The Yarragadee is too deep to underlie the Superficial Aquifer in most areas but it does subcrop in the extreme north and underlies the Wanneroo Member between Guilderton and Gingin, an important intake area of this aquifer. The Leederville Aquifer is often separated from the Superficial Aquifer by the Kardinya Shale (Osborne Formation) and the 

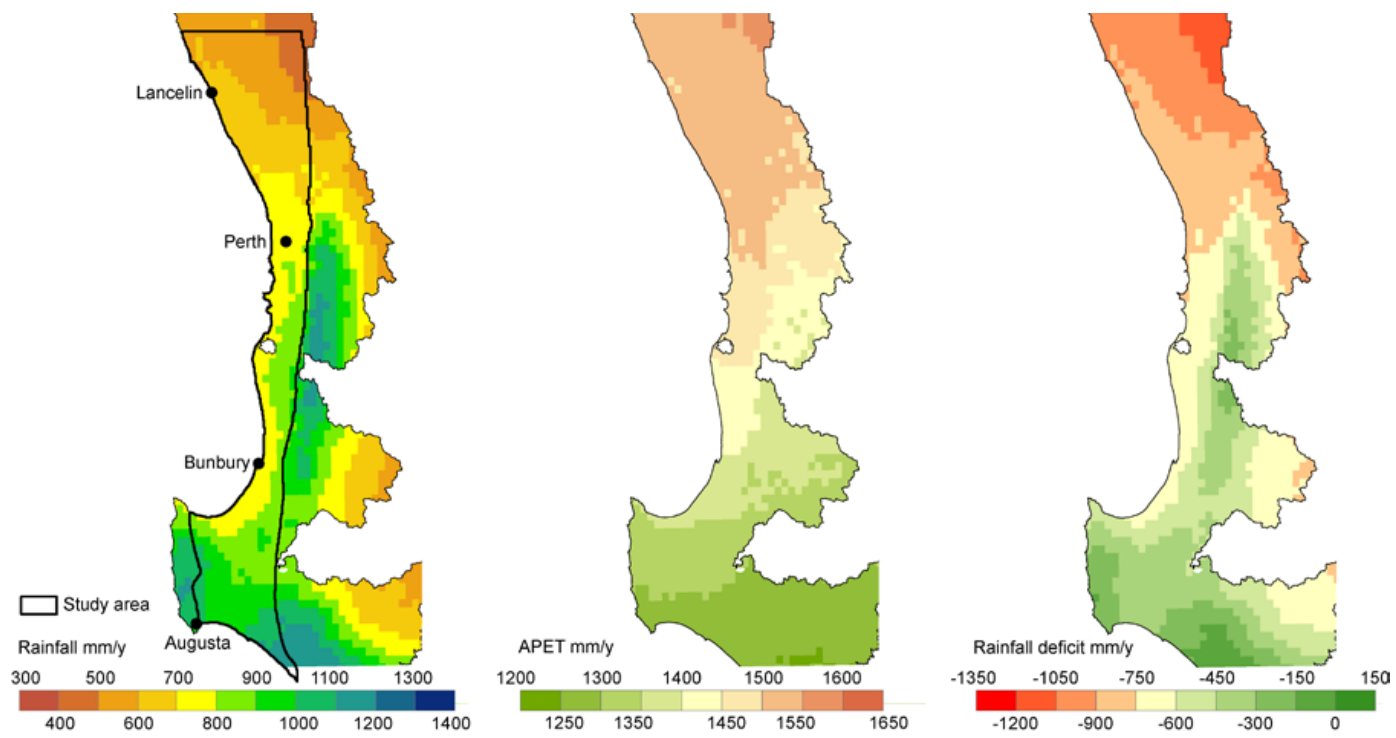

Fig. 2. Spatial distribution of mean annual historical (1975 to 2007) rainfall, areal evapotranspiration (APET) and rainfall deficit (rainfall less areal potential evapotranspiration) across the study area.

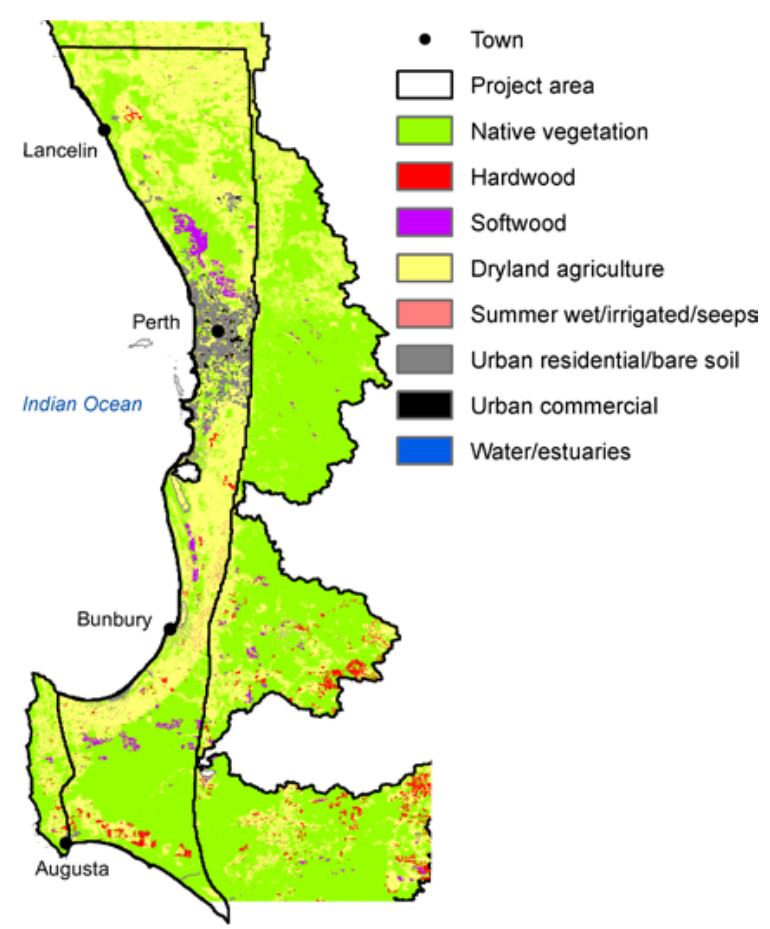

Fig. 3. Major land cover types in the study area (using satellite imagery from 2005).

Leederville is often separated from the Yarragadee Aquifer by the South Perth Shale (Fig. 4b).

Recharge by rainfall infiltration often decreases from the coast to the east because of decreasing rainfall and sediments becoming clayey in the east. Recharge can also occur from upward leakage from underlying formations where there are upward hydraulic gradients and confining beds are absent. Recharge rates vary depending on rainfall, lithology, depth to water table and topographic gradient and land cover. Groundwater discharge is to the ocean, to natural and engineered drainages and to coastal lakes. Large losses occur through evaporation from wetlands and in areas with shallow water tables. Groundwater flow is usually westwards towards the coast. The Gnangara Mound north of Perth and the Jandakot Mound south of Perth are the main flow systems. Further details about hydrogeology and confined aquifer systems of the Central Perth Basin can be found in CSIRO (2009) and Davidson (1995).

The Peel-Harvey Area extends between the coastal cities of Mandurah and Bunbury and the Darling Scarp (Fig. 5a). The major aquifers are the Superficial, Leederville and Cockleshell Gully (Fig. 5b) and their lithology and hydraulic conductivity is listed in Table 1. The Superficial Aquifer extends over the entire region and consists of the Bassendean Sands and the Ascot, Guildford and Yoganup formations. Its thickness ranges from 20 to $30 \mathrm{~m}$. The Superficial Aquifer is underlain by a number of confined aquifer systems including the Leederville, Cockleshell Gully and Yarragadee.

The water table is generally shallow in the area. Recharge mainly occurs through rainfall infiltration but some is rejected due to shallow water tables. Groundwater flow is towards the Indian Ocean in the west and discharges into the natural and engineered drainages, wetlands and ocean. Further details on the hydrogeology and confined aquifer systems of the Peel-Harvey Area are given in CSIRO (2009) and URS (2009a).

The Southern Perth Basin lies between the Darling and Dunsborough Faults and includes the easterly Bunbury Trough and westerly Vasse Shelf which are separated by 


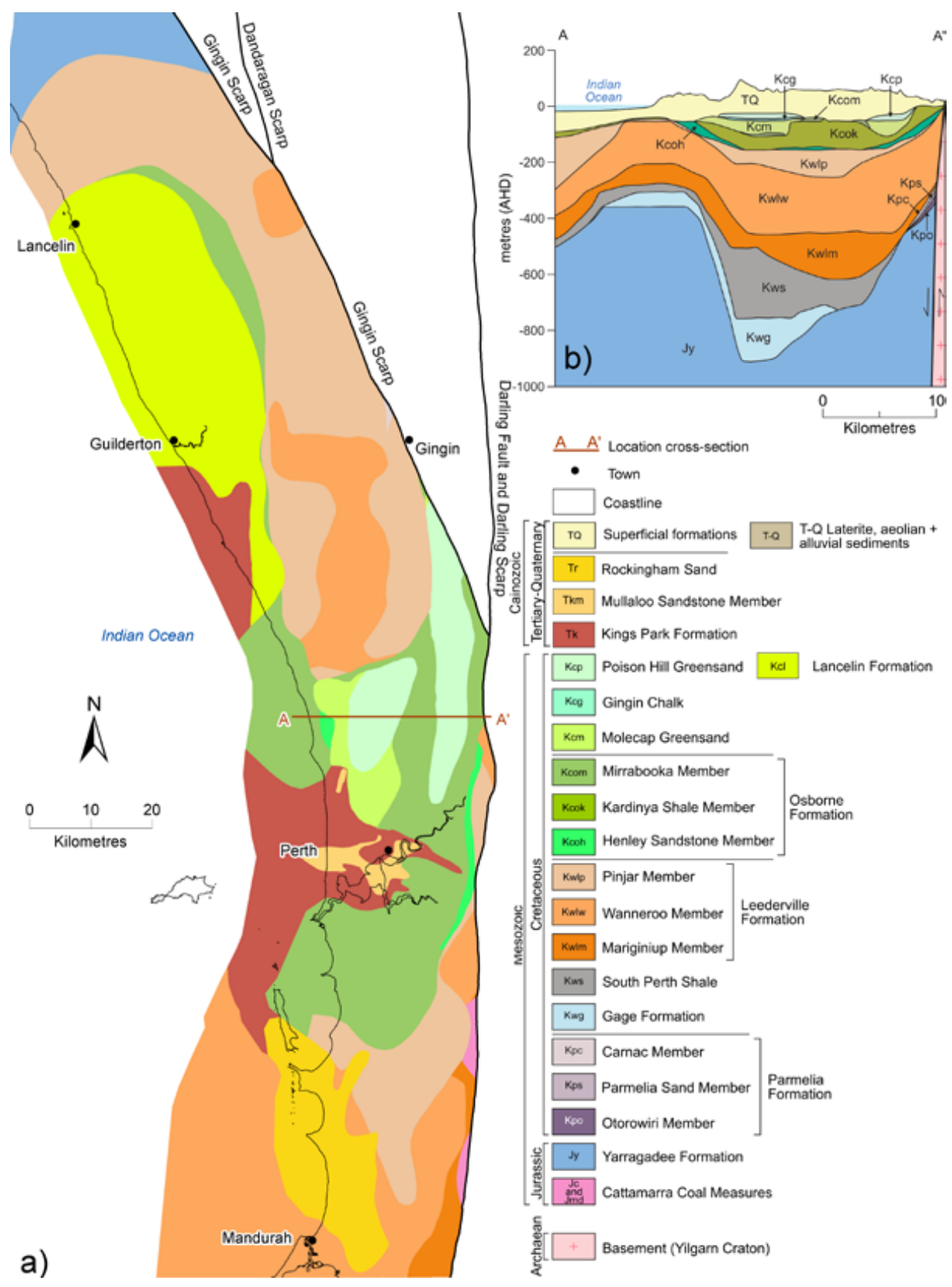

Fig. 4. Sub-surface geology of the Central Perth Basin (a) and geological cross-section A-A' (b) (adapted from Davidson and Yu, 2008).

the Busselton Fault (Fig. 6a, b). Major aquifers include the Superficial, Leederville and Yarragadee (Baddock, 2005) (Fig. 6b); their lithology and hydraulic conductivities are listed in Table 1. The Lesueur Sandstone, Cockelshell Gully and Sue Coal Measures are minor aquifers. The Superficial Aquifer extends over the Swan Coastal and Scott Coastal plains. The Superficial Aquifer material is more uniform and sandy under the Scott Coastal Plain than under the Swan Coastal Plain, however the aquifer can be locally confined by a ferruginous cemented layer in the lower parts of the formation (Strategen, 2005). Its thickness is often less than
$10 \mathrm{~m}$ but is up to $200 \mathrm{~m}$ under the coastal sands. Three confining beds occur within the basin: the middle clay unit of the Parmelia Formation, the Bunbury Basalt and the upper Mowen/Quindalup Member of the Leederville Formation (Fig. $6 \mathrm{~b}$ and Table 1). The middle clay unit is about $35 \mathrm{~m}$ thick and extends over the Bunbury Trough beneath the Blackwood Plateau (Strategen, 2004). The overlying and underlying formations are the Bunbury Basalt or the Leederville Aquifer and the Yarragadee Aquifer, respectively. The Lesueur Sandstone extends throughout the Southern Perth Basin. The Cockelshell Gully Formation is overlain 


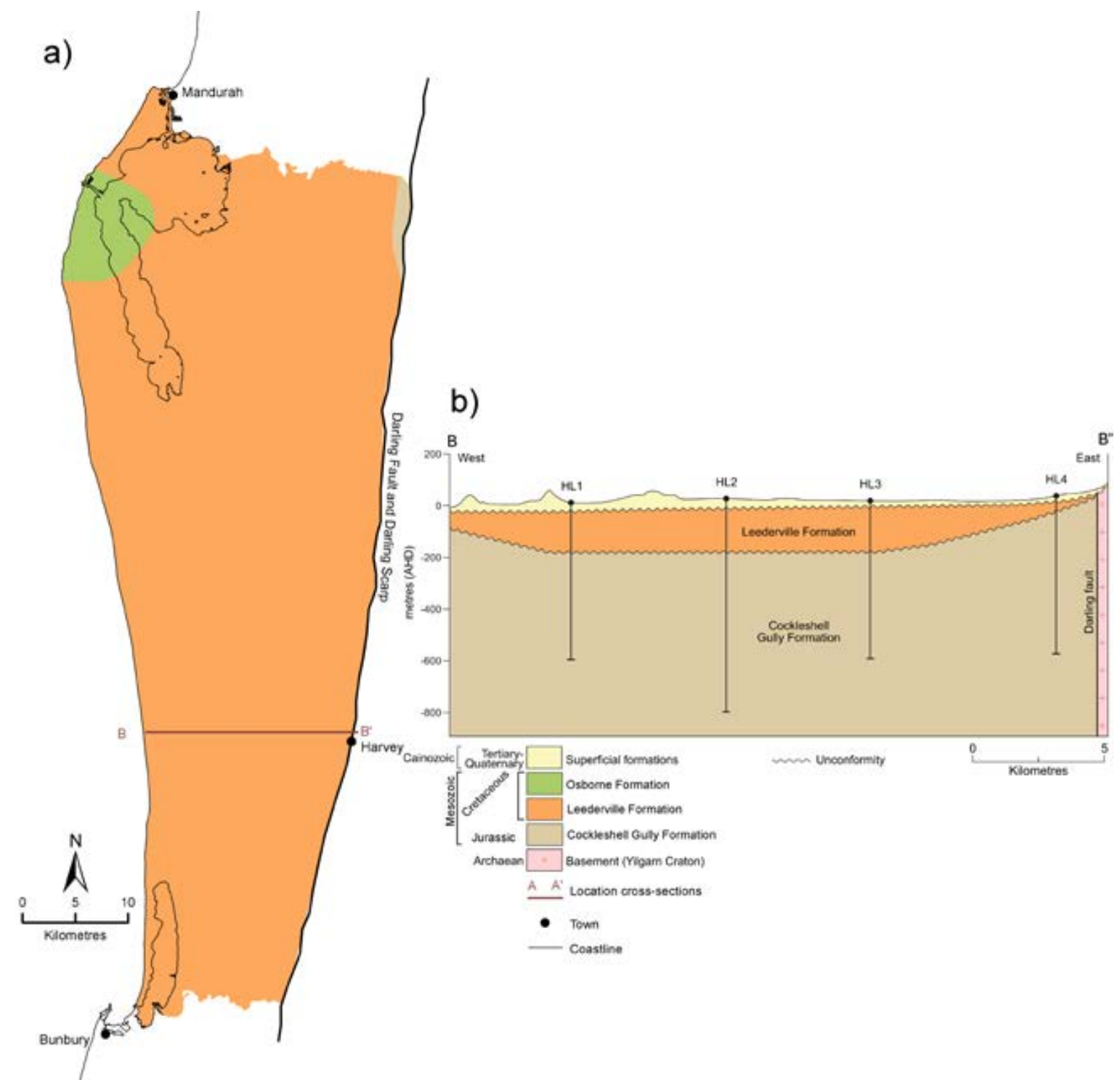

Fig. 5. Sub-surface geology of the Peel-Harvey Area (a) and geological cross-section B-B' (b) (adapted from URS, 2009).

by the Yarragadee Formation which is separated into the lower Yarragadee 4, Yarragadee 3, Yarragadee 2 and upper Yarragadee 1 (Fig. 6b).

On both Swan Coastal and Scott Coastal plains the Superficial Aquifer is mainly recharged by rainfall infiltration with some upward leakage from the underlying Leederville or Yarragadee aquifers near Bunbury within the Swan Coastal Plain and in the centre of the Scott Coastal Plain. The groundwater discharge is to the natural drainages, wetlands, ocean or to the underlying Leederville and Yarragadee aquifers. The main groundwater flow direction is to the north towards the Indian Ocean with some southerly flow towards the Southern Ocean. The Leederville and the Yarragadee outcrop over extensive areas and receive direct recharge from rainfall infiltration. Further details about hydrogeology of the con- fined aquifer systems of the Southern Perth Basin are given in CSIRO (2009) and Strategen (2005).

\subsection{Historical groundwater use and future demand}

Western Australia is faced with a scientifically complex challenge as the state relies heavily on groundwater systems which are difficult to quantify, due to their complex geology and hydrogeology, so that resource availability often requires sophisticated measurements (DoW, 2008a). Groundwater use has been sharply increasing over 30 -yr across all sectors in Western Australia. The annual abstraction from aquifers in the Central Perth Basin (Figs. 1 and 7a) trebled from 200 GL in 1985 to nearly $600 \mathrm{GL}$ in 2007 . Abstraction from the Superficial Aquifer in the Peel-Harvey Area (Figs. 1 and 7b) has increased from about 0.3 GL in 1994 to about 20 GL by 
Table 1. Lithology and estimated horizontal hydraulic conductivity of geological units in the study area (Davidson and Yu, 2006; Strategen, 2005; Sun, 2005; URS, 2009).

\begin{tabular}{|c|c|c|c|}
\hline & Formation & Lithology & $\begin{array}{l}\text { Horizontal hydraulic } \\
\text { conductivity } \\
\left(\mathrm{m}_{\text {day }}{ }^{-1}\right)\end{array}$ \\
\hline \multicolumn{4}{|c|}{ Central Perth Basin (PRAMS) and Peel-Harvey Area (PHRAMS) } \\
\hline \multirow{7}{*}{$\begin{array}{l}\text { Superficial } \\
\text { formations }\end{array}$} & Safety Bay sand & Sand and shelly sand & 10 to 15 \\
\hline & Becker sands & $\begin{array}{l}\text { Fine to medium grained quartz and } \\
\text { skeletal sand with lenses of } \\
\text { calcareous clay }\end{array}$ & 8 \\
\hline & Tamala limestone & $\begin{array}{l}\text { Limestone with weathered beds of } \\
\text { sand, marl and mud present at the base }\end{array}$ & $\begin{array}{l}100 \text { to } 1000 \text { for limestone } \\
7 \text { to } 35 \text { for sandy beds }\end{array}$ \\
\hline & Bassendean sand & Sand and subordinate silt and clay & 10 to 50 \\
\hline & Guildford Fm & Clay with subordinate sand and gravel & $<0.1$ to 1 \\
\hline & Yoganup Fm & Sand, silt, clay and pebbles & 8 to 10 \\
\hline & Ascot Fm & Limestone, sand, shells and clay & 3 to 16 \\
\hline Rockingham sand & Rockingham sand & $\begin{array}{l}\text { Slightly silty medium to } \\
\text { coarse-grained sand }\end{array}$ & 20 \\
\hline Kings Park Aquifers & Kings Park Aquifers & $\begin{array}{l}\text { Poorly sorted fine to coarse-grained } \\
\text { clayey sand }\end{array}$ & 10 to 15 \\
\hline \multirow{2}{*}{ Osborne Fm } & Mirrabooka & $\begin{array}{l}\text { Interbedded sandstone, siltstone and } \\
\text { shale sequence }\end{array}$ & 4 to 10 \\
\hline & $\begin{array}{l}\text { Osborne Fm } \\
\text { (Kardinya Shale Member) }\end{array}$ & Shale, siltstone, minor sandstone & $10^{-4}$ to $10^{-6}$ \\
\hline \multirow{5}{*}{ Leederville Fm } & Leederville & Sandstone, siltstone and shale & 0.2 to 9 \\
\hline & Henley Sandstone & Sandstone, shale & 2 to 3 \\
\hline & Pinjar & Sandstone, Siltstone and shale & 1 to 2 \\
\hline & Wanneroo & Sandstone, siltstone, and shale & 1 to 5 \\
\hline & Mariginiup & Sandstone, siltstone and shale & 0.1 to 1 \\
\hline South Perth Shale & South Perth Shale & Shale, siltstone and minor sandstone & $10^{-4}$ to $10^{-6}$ \\
\hline \multirow{3}{*}{ Parmelia Fm } & Carnac & Siltstone and shale & $10^{-6}$ \\
\hline & Parmelia & Sandstone, siltstone and shale & 0.5 to 2 \\
\hline & Ottorowiri & Siltstone and shale & $10^{-6}$ \\
\hline \multirow{3}{*}{ Yarragadee } & Yarragadee & Sandstone, siltstone and shale & 1 to 3 \\
\hline & Gage & Sandstone, siltstone and shale & 2 to 10 \\
\hline & Cattamarra & Sandstone, siltstone and shale & 1 to 3 \\
\hline Cockleshell Gully & & Sandstone, siltstone, claystone coal & 1 to 8 \\
\hline \multicolumn{4}{|c|}{ Southern Perth Basin (SWAMS) } \\
\hline Superficial Fm & Superficial & Sand, clay, limestone and gravel & 1 to 10 \\
\hline \multirow{2}{*}{ Leederville FM } & Quindalup/Mowen Members & Clay and silty clay & 0.1 to 0.5 \\
\hline & Vasse Member & Sand beds & 0.1 to 10 \\
\hline \multirow[t]{2}{*}{ Parmelia Fm } & Parmelia Fm & Clay with a lower portion of silt and sand & 0.005 to 0.05 \\
\hline & Bunbury Basalt & Rock and weathered clay & $10^{-7}$ to $10^{-6}$ \\
\hline \multirow{4}{*}{ Yarragadee } & Yarragadee 1 & Sandstone, siltstone and shale & 5 to 25 \\
\hline & Yarragadee 2 & Sandstone, siltstone and shale & 3 to 20 \\
\hline & Yarragadee 3 & Sandstone, siltstone and shale & 3 to 25 \\
\hline & Yarragadee 4 & Sandstone, siltstone and shale & 2 to 15 \\
\hline Cockleshell Gully Fm & Cockleshell Gully Fm & Sandstone, siltstone, claystone coal & 1 to 8 \\
\hline Lesueur sandstone & Lesueur sandstone & Sandstone and minor siltstone & 0.2 to 5 \\
\hline
\end{tabular}




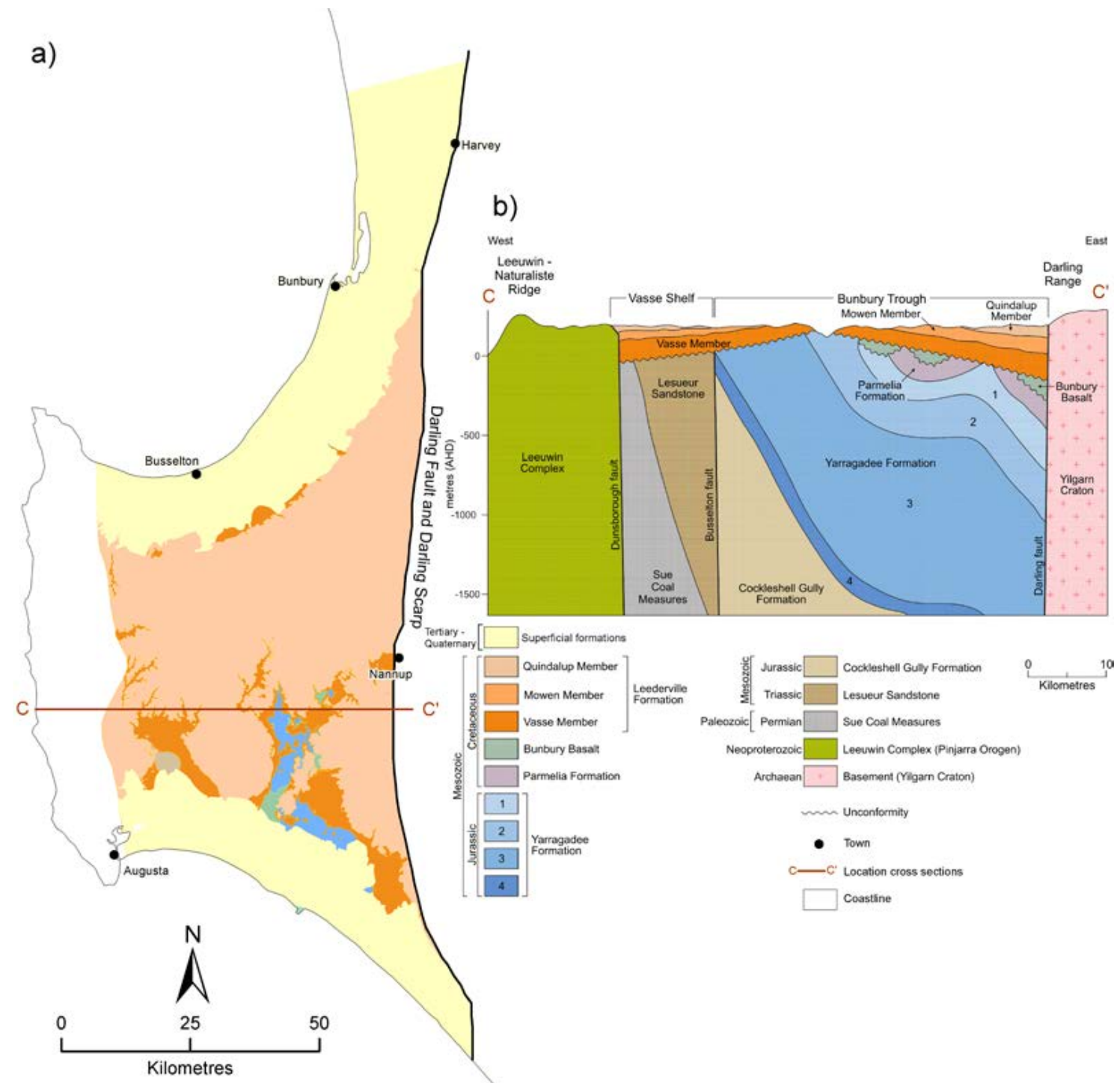

Fig. 6. Surface geology of the Southern Perth Basin (a) and geological cross-section C-C' (b) (adapted from DoW, 2008b).

2007. The total annual abstraction from the Southern Perth Basin (Figs. 1 and 7c) increased from 0.5 GL in 1985 to about $75 \mathrm{GL}$ in 2007.

In the study area the estimated total groundwater use in 2007 was about 700 GL. Groundwater demand is projected to increase further with population and industrial growth, and depleting surface water supplies (CSIRO, 2009). The future population growth within the study area is likely to be centred on the Greater Perth area, the Bunbury area, the coastal area between Bunbury and Busselton and the Shire of Augusta-Margaret River, and will therefore have increased demand for water (DoW, 2007).

\section{Methods}

A flow diagram of the main methods (models and datasets) used in this study is shown in Fig. 8. Recharge was estimated using a vertical flux model (VFM) (Barr et al., 2003) linked with three groundwater models: the Perth Regional Aquifer Modelling System (PRAMS) of the Central Perth Basin; the South West Aquifer Modelling System (SWAMS) of the Southern Perth Basin; and the Peel-Harvey Regional Aquifer Modelling System (PHRAMS) of the Peel-Harvey Area. The PRAMS was previously dynamically coupled with the VFM. In this study the VFM was dynamically coupled with the MODFLOW based SWAMS model making it able to estimate the water table depth at each simulation period which is required to estimate the recharge and discharge amounts. For PHRAMS the rainfall-recharge modelling was done using 


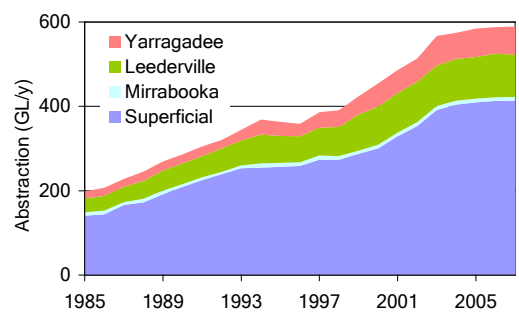

(a)

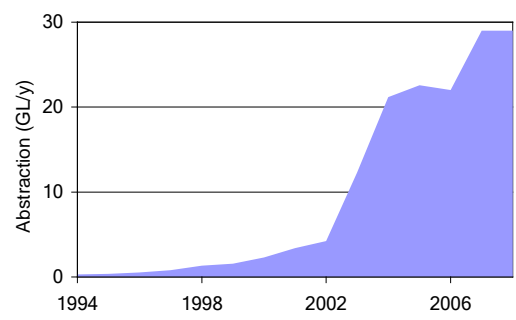

(b)

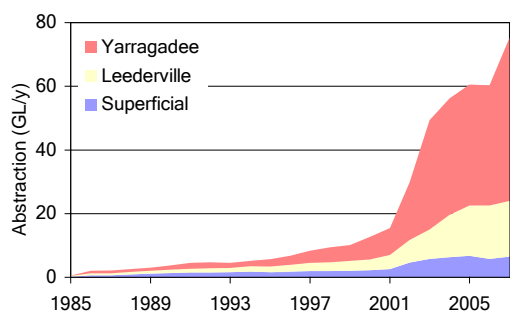

(c)

Fig. 7. Abstraction from four aquifers between 1985 and 2007 in the Central Perth Basin (a), licensed allocation from the Superficial Aquifer between 1994 and 2007 in the Peel-Harvey Area (b), and abstraction from three aquifers between 1985 and 2007 in the Southern Perth Basin (c).

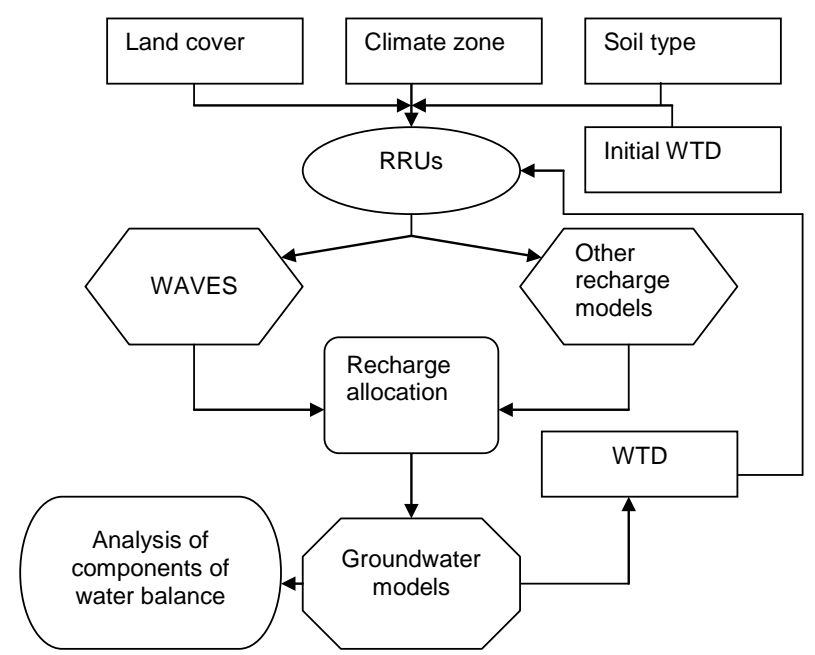

Fig. 8. A flow diagram showing main methodologies (models and datasets) used for the study (WTD: water table depth; RRU: recharge response unit).

a linked but not dynamically coupled VFM. Groundwater models (PRAMS, SWAMS and PHRAMS) were used for scenario modelling. The modelling results were analysed to estimate the climate change impacts on various components of the water balance.

\subsection{Recharge estimation}

The VFM calculates recharge to, and discharge from, an aquifer system. "VFM Manager" incorporates a number of different recharge models such as WAVES (water, atmosphere, vegetation, energy simulation; Zhang and Dawes, 1998) and other simple empirical models (Barr et al., 2003). WAVES is a 1-dimensional biophysical model and simulates vertical water flow through soil and water uptake by vegetation such as pasture, pine plantations and Banksia woodlands. Simple empirical models are used for urban areas, market gardens, wetlands and areas where water tables are close to the soil surface. Two of these simple models include a "linear vertical flux model" and a "piece-wise linear vertical flux model". For the linear vertical flux model a constant multiplier for the rainfall and potential evaporation is used to calculate recharge as (Barr et al. 2003):

$R=\left(C_{\text {rainfall }} \times P\right)-\left(C_{\text {evap }} \times E\right)$

where $R$ is the rate of recharge per unit surface area in a cell; $C_{\text {rainfall }}$ is the multiplier for the rainfall in that cell; $P$ is the rainfall per unit surface area per unit time; $C_{\text {evap }}$ is the multiplier for the evaporation; and $E$ is the potential evaporation per unit surface area per unit time.

The "piece-wise linear flux model" is based on a piecewise linear relationship about critical water table depths for both rainfall and evaporation. The critical water table depths may be different for the rainfall and evaporation and a multiplier ( $C_{\text {rainfall }}$ and $\left.C_{\text {evap }}\right)$ is supplied for each critical water table depth. This is expressed in Eq. (2) (Barr et al., 2003):

$$
\begin{aligned}
& \text { WT } \leq \text { Depth }_{\text {lowest }}: \text { MLT }=\text { Multiplier }_{\text {lowest }} \\
& \text { WT } \geq \text { Depth }_{\text {highest }}: \text { MLT }=\text { Multiplier }_{\text {highest }} \\
& \text { Depth }_{i-1}<\text { WT }<\text { Depth }_{i}: \text { MLT } \\
& =\frac{\left(\text { Multiplier }_{i}-\text { Multiplier }_{i-1}\right)}{\left(\text { Depth }_{i}-\text { Depth }_{i-1}\right)} \\
& *\left(\text { WT }- \text { Depth }_{i-1}\right)+\text { Multiplier }_{i-1}
\end{aligned}
$$

where MLT is the multiplier for the climate quantity (it may be $C_{\text {rainfall }}$ or $C_{\text {evap }}$ ) at the specified water table depth; WT is the given water table depth; Depth $_{i}$ is the $i$ th specified depth; and Multiplier ${ }_{i}$ is the multiplier associated with that depth.

The VFM estimates aquifer recharge or discharge from inputs of climate; land cover; soil type; and water table depth as shown in Fig. 8. Before running the VFM, the grid cells of similar attributes are grouped together into recharge response units (RRUs) based on climate zone, soil type, and land cover. For grouping into RRUs the study area was divided into 12 climate zones based on rainfall and evaporation gradients. The future climate data, for each climate zone, was derived following the procedure described in Sect. 3.3. The study area was also divided into 14 land cover classes. 
The current land cover (2007) and LAI (leaf area index) remained constant for all future scenarios, except the development scenario, although McCallum et al. (2010) noted possible changes in LAI under projected future climate scenarios. The soil units were grouped into 11 soil types of similar hydrological properties and texture based on Australian Soils Resource Information System (ASRIS) level 4 data. For each RRU the VFM estimated the recharge and discharge rates at each stress period by obtaining the water table depth from the groundwater model.

\subsection{Groundwater models - description and calibration}

Three groundwater models (PRAMS, SWAMS and PHRAMS) distributed recharge from the VFM into various components of the water balance using numerical schemes of the physical processes.

The VFM coupled PRAMS model, used for the Central Perth Basin, covers an area of about $10000 \mathrm{~km}^{2}$ between Mandurah in the south and Dandaragan in the north (Fig. 1). It is a finite difference MODFLOW-based model (McDonald and Harbaugh, 1996) with a uniform grid size of 500 by $500 \mathrm{~m}$ (Cymod, 2009). The version 3.2 of the model has 13 layers representing various aquifers and confining beds. The western boundary in the superficial aquifer was modelled as a constant head with a head of $0.5 \mathrm{~m}$. A constant head boundary was also assigned to the first set of faults lying off the Western Australian coast in layer 4 of the model. No flow boundary conditions were assigned in the Leederville and Yarragadee aquifers. The eastern Darling Fault boundary was set as no-flow for all model layers. The southern and northern boundaries were also set as no-flow boundaries since flow direction in the superficial aquifer is almost parallel to these boundaries. Since most drainages act as groundwater discharges these were modelled as drains in MODFLOW. Groundwater discharge to these drains occurs once the water table rises above the specified drain invert level.

In the VFM the upper surface of the model was defined as the top of layer 0 . The two boundaries of the VFM were the ground surface and the water table. At groundwater surface the VFM models a number of processes (rainfall, insolation, wind and plant growth). The conditions on ground surface boundary were specified as part of the input to the VFM. The VFM estimated daily net recharge to a $500 \times 500 \mathrm{~m}$ soil column, ranging in depth from 1 to $50 \mathrm{~m}$. This daily recharge was aggregated over the MODFLOW stress period and provided as net recharge to the saturated aquifer model. The integration of VFM into the MODFLOW effectively replaced the EVT module. The VFM estimated net rainfall recharge was the major source of water into the model. The other boundary conditions, such as constant heads on the coast and drains within the model domain typically discharged water from the model. Groundwater abstraction by the Water Corporation and licensed and unlicensed groundwater abstraction by private users was included in the calibration. The re- turn groundwater flow to the superficial aquifer from irrigation was taken into account by reducing the licensed and unlicensed abstraction from the Superficial Aquifer by 20 and $30 \%$, respectively.

The quasi steady-state VFM-coupled PRAMS model was calibrated by adjusting vertical and horizontal hydraulic conductivities, storage coefficients and specific yields and by setting licensed and unlicensed abstraction to that estimated in 1980. The calibration and validation periods of the transient VFM-coupled PRAMS model were from 1985 to 2003 and from 2004 to 2008, respectively (Cymod, 2009). All together groundwater monitoring data (water table and heads) from 862 bores were used for calibration. The model calculated and measured groundwater levels were compared and aquifer parameters adjusted to minimise error. The residual error between measured and calculated heads indicates deficiencies either in the calibration process or the conceptual model. The model calibration error (Root Mean Squared Error, RMSE) was $2.1 \mathrm{~m}$ for the Superficial Aquifer. The model calculated water levels show a random distribution around the unity line with little or no systematic deviation (Fig. 9). The simulated water levels have a response consistent with measured data, they maintain correct trends and magnitude of error is constant which suggests that the error stems from initial conditions. The spatial distribution of error shown in Fig. 9 also suggests that the calibration error is typically less than $2 \mathrm{~m}$ over most of the model domain. However there are few areas where the error is relatively large.

The VFM-coupled SWAMS version 2.1 model, used in the Southern Perth Basin, covers an active area of about $8500 \mathrm{~km}^{2}$ of which onshore area is approximately $6000 \mathrm{~km}^{2}$. The model boundaries extend from the Brunswick River north of Bunbury to the Warren River south of Pemberton, and from the Dunsborough Fault in the west to the Darling Scarp to the east (Fig. 1). It is a variable finite difference grid, with 363 rows and 193 columns, rotated 4.5 degrees anti-clockwise from north. The cell size varies from 250 by $250 \mathrm{~m}$ to 1000 by $1000 \mathrm{~m}$. Eight layers of the model represent the major aquifers and aquitards in the region.

In the Southern Perth Basin all groundwater resources originate from rainfall recharge to the Superficial and Leederville aquifers and to the Yarragadee Aquifer where it outcrops. The northern and southern ocean model boundaries were set as constant head of $0 \mathrm{~m}$ in the Superficial Aquifer. Constant head boundaries were also defined for off-shore submerged areas of layer 2 and the aquifer limits off-shore for layers 3 to 8 in the north and south. It allowed upward flow and groundwater discharge as described in the hydrogeology investigations by Baddock (2005). The Southern Perth Basin is bounded by major faults on the east and the west which permit no flow into or out of the model (no flow boundaries on the east and west). All drainages were modelled as drains to represent groundwater discharge to river systems. 

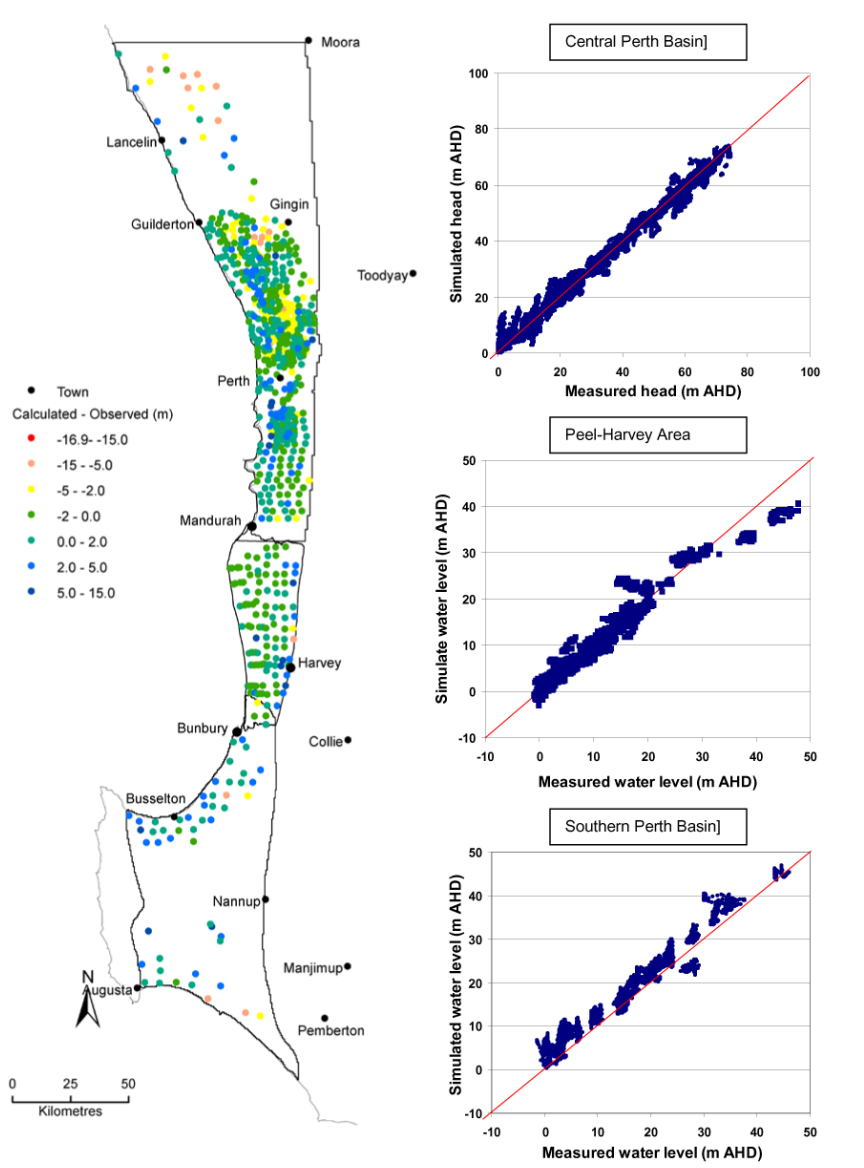

Fig. 9. Comparison of the model calculated and measured water levels and spatial distribution of error in the Superficial Aquifer for the PRAMS, SWAMS and PHRAMS.

The VFM coupled SWAMS model was calibrated from 1990 to 2000 using 54 bores in the Superficial Aquifer, 98 calibration bores in the Leederville Aquifer, and 88 calibration bores in the Yarragadee Aquifer. Measured heads were compared with model calculated heads and aquifer parameters adjusted to minimise the error. All measured groundwater abstraction by the Water Corporation (public licensed) and by other users such as mining companies, regional councils, and licensed private users was included in model calibration. The Superficial Aquifer calibration error was $2.9 \mathrm{~m}$ (RMSE) (CSIRO, 2009). The calibration error in the Superficial Aquifer (Fig. 9) shows that model calculated water levels are consistently higher than measured levels. The width of distribution suggests the presence of some calibration error between measured and calculated water levels. The model validation spanned between 2000 and 2008 with an error of $3.3 \mathrm{~m}$ (RMSE). Model calculated water levels during the validation period typically follow measured trends in the Superficial Aquifer. The error is almost randomly distributed around the unity line. Model also underpredicts at some locations which may be due to lack of information about hydro- geology, monitoring data and groundwater abstraction. The spatial distribution suggests that the calibration error is small in some areas and relatively large ( 2 to $5 \mathrm{~m}$ ) in others (Fig. 9).

For the Peel-Harvey Area a newly developed PHRAMS covers an area of $4095 \mathrm{~km}^{2}$ between the Peel Inlet and Bunbury (Fig. 1). This model was not coupled with VFM. Its boundary extends from the Darling Fault to the east to the Indian Ocean to the west, and the South Dandalup River, the Murray River and Peel Inlet to the north to the Collie River to the south. Visual MODFLOW Version 2009.1 Pro with MODFLOW-SURFACT Version 3.0 was used for the construction of the PHRAMS for the Superficial Aquifer. The model consists of 6 layers; upper three layers represent the Superficial Aquifer and lower three layers represent the underlying confined formations. Since it was a Superficial Aquifer model the spatial discretisation focused on this aquifer. It has a uniform grid of 500 by $500 \mathrm{~m}$. The conceptual hydrogeology suggests that all groundwater resources originate from rainfall recharge. Since groundwater levels are shallow all drainages were modelled as drains. The eastern Darling Fault boundary was assumed as no flow since no significant flow enters the model from this boundary. The western boundary was assumed as a constant head of $0 \mathrm{~m}$ AHD for the Superficial Aquifer (layers 1 to 3) and $2.5 \mathrm{~m}$ AHD for the offshore (layers 4 to 6 ) confined aquifers to represent groundwater discharge from these aquifers into the Ocean as upward flow. The northern and southern boundaries were assumed as river boundaries.

Groundwater abstraction by licensed private users, regional councils for town water supplies and industrial users was used for model calibration. The model calibration period spanned between 1980 and 2002 and used groundwater monitoring data (water levels) from 162 observation wells. The model calibration error was $1.83 \mathrm{~m}$ (RMSE). The model calculated water levels follow measured trends (Fig. 9) and the error is randomly distributed around the unity line. Relatively large deviation of model calculated water levels from the measured levels at some locations is most likely due to lack of hydrogeology, groundwater monitoring or groundwater abstraction data. The spatial distribution of error is relatively small in most areas (Fig. 9). The mode validation period was from 2003 to 2007 and validation error was similar $(1.88 \mathrm{~m})$ to that for the transient calibration.

The maximum potential recharge rates were provided as input and the net recharge rate was estimated internally using the evapotranspiration (EVT) package of MODFLOW. The EVT package in Visual MODFLOW simulates the effects of plant transpiration and direct evaporation and requires evapotranspiration rate that occurs when the water table is equal to the top of the grid cell and extinction depth (the depth below the top of grid cell elevation where the evapotranspiration is negligible). The extinction depth of $2 \mathrm{~m}$ was assumed for agriculture land and $5 \mathrm{~m}$ for native forests and plantations. The VFM was used to estimate recharge rates from input of land use, vegetation type, soil type, climate zone 
and water table depth. Irrigation recharge from irrigated areas was added to rainfall recharge. Further details about this model are given in URS (2009b).

Using these groundwater models the impacts on components of the water balance under six modelling scenarios (five climates and one development scenario) were assessed. For modelling purposes the groundwater abstractions were kept constant at 2007 levels in all scenarios except the development scenario where they were increased to full allocation levels.

\subsection{Modelling scenarios}

The following procedure was used for deriving the future climate data for the six modelling scenarios.

1. The historical climate scenario was based on the climate of the 1975 to 2007 period. It was assumed that the subsequent $33 \mathrm{yr}$ would have the same climate. For reporting groundwater conditions in 2030 the historical climate data of 23 yr duration (2008-2030) was selected from $33 \mathrm{yr}$ of observed climate data between 1975 and 2007. Using a sequence approach 11 sequences of 23 consecutive years were derived. The first sequence included $23 \mathrm{yr}$ of observed climate data from 1975 to 1997, the second sequence included 1976 to 1998, and the last sequence was $23 \mathrm{yr}$ of observed climate data from 1985 to 2007 . The climate data in these 11 sequences were then used in the WAVES model to estimate recharge rates. The average recharge rates were ranked from lowest to highest for 11 sequences and the sequence that represented 50th percentile recharge was selected. In the selected 50th percentile sequence the remaining $10 \mathrm{yr}$ of the climate data were added to make $33 \mathrm{yr}$ and this constituted the historical climate. The remaining $10 \mathrm{yr}$ of climate data were added to extend the historical climate to 2040 for simulation with groundwater conditions in 2030 being reported. This historical climate scenario was used as the baseline against which other scenarios were compared.

2. The recent climate scenario was used to assess the impacts on water balance should the climate between 2008 and 2030 prove to be similar to that of the recent past. Climate data for $11 \mathrm{yr}$ (1997 to 2007 inclusive) were repeated three times until 2040 with the conditions in 2030 being reported.

3.-5. The daily downscaling approach outlined by Chiew et al. (2009) was used to derive fine resolution climate data from coarse resolution GCM projections. This approach is based on pattern scaling (Mitchell, 2003) with additional scaling to account for the projected changes in daily rainfall intensity (Mpelasoka and Chiew, 2009). The scenarios were developed on a "per degree of global warming" basis. Firstly, monthly rainfall and other climate variables for 1870-2100 were obtained for 15
GCMs, selected based on availability of daily rainfall data, from those used in the Intergovernmental Panel on Climate Change 4th Assessment Report (IPCC, 2007). For each GCM, season, and GCM grid point these outputs were linearly regressed against simulated global average surface air temperature to give percent change in each variable per degree of global warming. Secondly, daily scaling factors for rainfall intensity were obtained based on GCM simulated changes to daily rainfall percentiles (also by GCM, season and GCM grid point) and expressed as percent change per degree of global warming (Chiew et al., 2009). These seasonal and daily scaling factors were multiplied by the low, medium and high global warming scenarios, $0.7^{\circ} \mathrm{C}, 1.0^{\circ} \mathrm{C}$ and $1.3^{\circ} \mathrm{C}$, to account for the full range of the IPCC AR4 projections for 2030. The historical time series for all $0.05^{\circ}$ grid cells within the study area were modified by the 45 sets of seasonal and daily scaling factors ( $15 \mathrm{GCMs} \times 3$ global warming scenarios) to produce an ensemble of daily rainfall and PET scenarios encompassing the projected range of climate change for the region. Results and discussion of this approach can be found in detail in Charles et al. (2010).

For each of the low, medium and high global warming scenarios and each of the 15 climate series, the mean annual recharge over the study area was estimated using the WAVES model in de-coupled mode. The estimated recharge rates from each of the 15 climates were ranked separately for the low, medium and high global warming. GCMs considered unreliable in terms of reproducing southern hemisphere weather phenomena and historical rainfall patterns over south-west Western Australia were discarded and the dry, median and wet selected from those remaining. The selected GCMs were $\mathrm{GFDL}+1.3^{\circ}$ for the dry future climate, MIROC $+1{ }^{\circ} \mathrm{C}$ for the median future climate, and INMCM $+1.3^{\circ} \mathrm{C}$ for the wet future climate. The GFDL was developed by the Geophysical Fluid Dynamics Laboratory located at Princeton University. The MIROC (model for interdisciplinary research on climate) was jointly developed by the Center for Climate Systems Research at University of Tokyo (CCSR), National Institute of Environmental Studies (NIES) and Frontier Research Center for Global Change (FGCGC). The INMCM was developed at the Institute of Numerical Mathematics (INM) of the Russian Academy of Sciences and at the main Geophysical Observatory (MGO).

To select the historical climate sequence, from which future climates were to be derived by applying scaling factors of the above selected GCMs, the average annual recharge from 23 -yr sequences were ranked. The climate sequence from 1984 to 2006 was selected as the representative period for simulation of the 2008 to 2030 . This climate sequence was modified by the 
scaling factors of the above GCMs to derive (3) the dry future climate, (4) the median future climate, and (5) the wet future climate.

6. The development scenario was based on the median future climate and future land development. The groundwater abstraction was increased to full allocation levels from the start of 2008 where this was below 2009 allocation limits. In the Gnangara Mound area of the Central Perth Basin the scheduled legislated removal of the pine plantations and expansion of the urban area was allowed to take place between 2008 and 2030 .

\subsection{Water balance components}

The groundwater models estimate various components of aquifer water balance. These water balance components can be expressed as

$R=S_{\mathrm{sc}}+D_{\mathrm{disch}}+O_{\mathrm{disch}}+A_{\mathrm{abs}}+F_{\mathrm{conf}}+E$

where $R$ is net recharge, i.e. the amount of water that is added to the aquifer less losses through evapotranspiration; $S_{\mathrm{sc}}$ is storage change in an aquifer; $D_{\text {disch }}$ is the groundwater discharge to natural and engineered drainage systems; $O_{\text {disch }}$ represents discharge to the ocean; $A_{\text {abs }}$ is total groundwater abstraction by pumping; $F_{\text {conf }}$ is net leakage to confined aquifer systems; and $E$ represents error in water balance. All terms have units of $\mathrm{mm}$ per unit time, or volume per unit aquifer area.

\section{Results}

\subsection{Climate change impacts on rainfall}

Since 1975 the mean annual rainfall in south-western Australia has decreased by about 15 percent from the long-term average. The projected mean annual rainfall between 2008 and 2030 under the climate scenarios is shown in Fig. 10 for three regions in south-western Australia. The projected rainfall is highest in the Peel-Harvey Area and lowest in the Central Perth Basin under all scenarios. Relative to the historical climate the mean annual rainfall under all future climate scenarios is projected to reduce in all three regions except under the wet future climate in the Central Perth Basin. Relative to the historical climate the largest reduction of between 15 and 18 percent is expected under the dry future climate (Fig. 10).

\subsection{Overall water balance}

The overall Superficial Aquifer water balance between 2008 and 2030 in Appendix A shows the distribution of net recharge into storage change and various discharges in the three regions. Positive numbers in this table indicate additions to storage and negative numbers indicate losses.

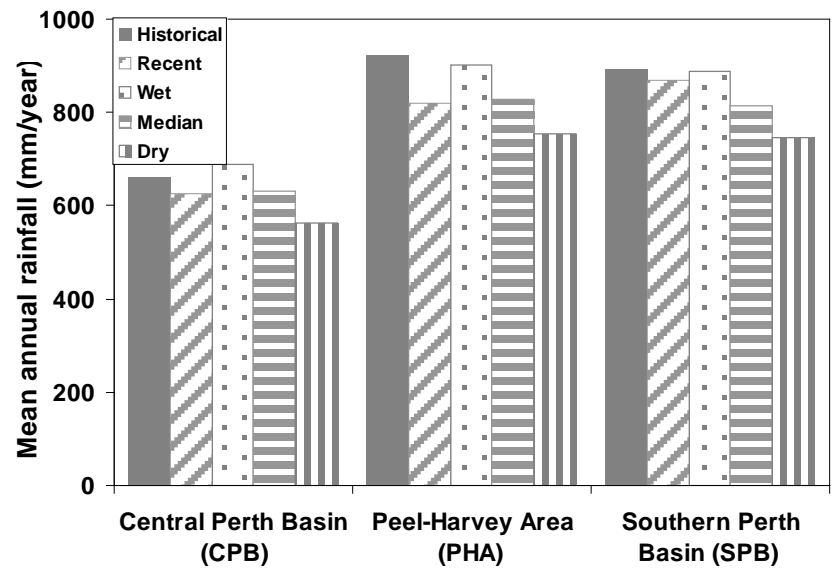

Fig. 10. Mean annual rainfall in the Central Perth Basin, PeelHarvey Area and Southern Perth Basin under various future climate scenarios.

Pumped abstraction is constant under all except the development scenario. Net leakage to the confined aquifers occurs in the Central and Southern Perth basins where the unconfined and confined aquifers are inter-connected. The 23-yr mean annual value of each water balance component in megalitres (ML, $\left.10^{6} \mathrm{~L}\right)$ is divided by total surface area of the Superficial Aquifer $\left(\mathrm{km}^{2}\right)$ in each region to convert into $\mathrm{mm}$ per year for a meaningful comparison between the regions. The overall water balance error was small with its value less than the significant digits (Appendix A). The changes in rainfall, recharge and other components of the water balance are reported relative to a continuation of the historical climate of 1975-2007 to 2030.

\subsection{Climate change impacts on groundwater recharge}

The water levels are projected to rise in the north-east of the region due to clearing of native vegetation for dryland agriculture, sandy soils and low groundwater abstraction and to fall in the south under the Blackwood Plateau due to native vegetation and clayey soils under a median future climate (Fig. 11) and under most other scenarios. They are projected to remain relatively unchanged in the Peel-Harvey Area. The highest recharge is expected in the Central Perth Basin and lowest in the Peel-Harvey Area despite the rainfall being higher in the latter (Fig. 12; Appendix A). It is highest in the Central Perth Basin due to several factors: a deeper water table (less evaporative losses), greater urban areas where stormwater is directed into the aquifer, and the presence of cleared sandy soils used for dryland agriculture. It is lowest in the Peel-Harvey Area due to widespread occurrence of the swampy areas that result in large evapotranspiration losses due to potential evaporation rates being two to three times greater than rainfall, and shallow water tables in many areas which reject rainfall due to saturation. The recharge rates are lower in the Southern Perth Basin than in the Central 


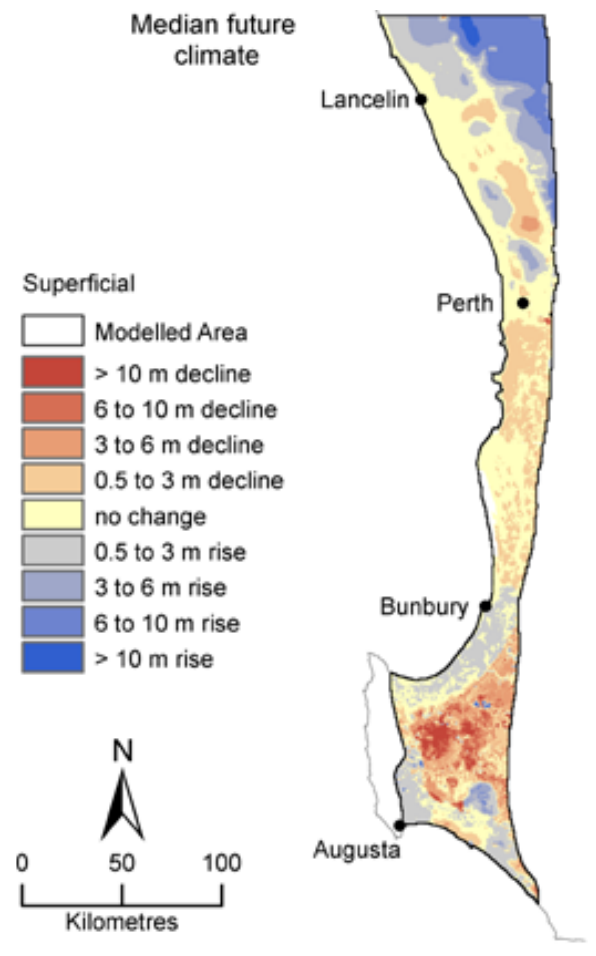

Fig. 11. Spatial distribution of change in groundwater levels over the period 2008 to 2030 in the study area under a median future climate.

Perth Basin despite its higher rainfall. This is due to native vegetation on most of the Blackwood Plateau together with widespread clayey soils both of which reduce net recharge.

The highest recharge is projected to occur under the historical and wet future climates and lowest under the dry future climate across all three regions (Fig. 12; Appendix A). Recharge under the median future climate may reduce by 1.5 to 4 times the rainfall reduction in relative terms, and by two to three times under a dry future climate.

\subsection{Impacts on Superficial Aquifer storage change}

The groundwater storage change is projected to be positive, i.e. gaining, and highest in the Central Perth Basin corresponding with larger net recharge rates, and lowest and mostly negative, i.e. losing, in the Peel-Harvey Area due to low net recharge rates (Fig. 12; Appendix A). The storage change of $39 \mathrm{~mm}$ per year increase under the historical climate is projected to reduce by 88 percent under the dry future climate in the Central Perth Basin. Based on regional averages no groundwater storage loss is expected under any scenario in the Central Perth Basin due to high recharge rates, especially in the north east of this region. Some areas will however experience significant declines in storage, especially under the dry future climate.

The storage is likely to remain stable if the historical climate continues into the future in the Peel-Harvey Area.

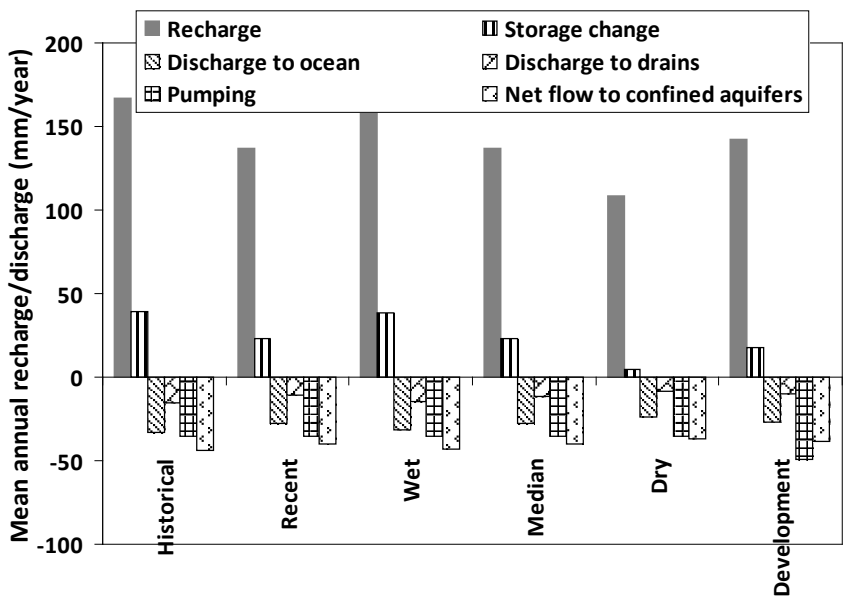

Fig. 12. Water balance components in the Superficial Aquifer of the Central Perth Basin from the 2008 to 2030 period under various scenarios. The values are 23-yr annual means under various scenarios.

Under the dry future climate an average loss in groundwater storage is expected in this area. The groundwater storage loss is highest under the development scenario due to increased pumping. However increased groundwater pumping also creates extra storage space to accommodate more recharge (Fig. 12; Appendix A).

The storage, when averaged at basin scale level, is projected to increase under all scenarios except the dry future climate in the Southern Perth Basin. There are areas within the basin, such as the Blackwood Plateau, where a groundwater storage loss is occurring. In these areas the groundwater levels have been declining in the past and are projected to decline further under the median and dry future climates. A net loss in groundwater storage is likely to occur under the dry future climate.

The dry future climate causes the largest reduction in groundwater storage across all three regions. It means if climate similar to the dry future eventuates in south-western Australia, the groundwater resource is likely to reduce over time in the Peel-Harvey Area and Southern Perth Basin and remain stable in the Central Perth Basin provided the current groundwater abstraction and land development conditions are maintained. This stability however masks substantial decreases in storage in important drinking water supply areas while areas under dryland agriculture may continue to have rising groundwater levels.

\subsection{Impacts on ocean groundwater discharge}

Climate change impacts groundwater levels which affect hydraulic gradients and groundwater discharge to the ocean. The mean annual groundwater discharge to the ocean is similar in the Central and Southern Perth basins and lower in the Peel-Harvey Area (Fig. 12; Appendix A). As expected, 
larger ocean discharges are expected under the wetter climate (historical and wet) and smaller under the drier climates (median and dry) in all three regions. Groundwater discharge to the ocean under the dry future climate is expected to reduce by 27 percent in the Central Perth Basin and by 38 percent in the Southern Perth Basin. Instead of groundwater discharge, seawater intrusion is likely in the Peel-Harvey Area under the dry future climate due to lower groundwater levels in coastal areas. Relatively large reductions in ocean discharge are expected under the median and dry future climates in the Central and Southern Perth basins due to lower groundwater levels, which increase the risk of seawater intrusion especially in conjunction with sea level rise projected due to climate change.

\subsection{Impacts on groundwater discharge to drains and rivers}

The mean annual groundwater discharge to drains and rivers is highest in the heavily drained Peel-Harvey Area and lowest in the relatively undeveloped Southern Perth Basin (Fig. 12; Appendix A). Substantial discharge is expected to occur to the drainage systems annually due to shallow water tables and an extensive network of natural and engineered drainage systems in the Peel-Harvey Area. Winter rainfall causes water tables to rise above the invert level of drainage systems in most of this area causing substantial groundwater discharges. Due to fewer river systems, lower groundwater levels and extensive native vegetation, groundwater discharge to river and drainage systems is relatively small in the Southern Perth Basin. Substantial reductions in groundwater discharge to drains are expected under the median and dry future climate, and the development scenario in all three regions. The reductions expected under the median and dry future climates are due to projected decline in water tables.

\subsection{Impacts on net leakage to confined aquifers}

The mean annual net leakage from superficial to confined aquifer systems is highest in the Central Perth Basin, lowest in the Southern Perth Basin, and zero in the Peel-Harvey Area due to the relative paucity of inter-connections with lower aquifers in this area. The net leakage to the confined systems is expected to reduce by 16 to 34 percent under the dry future climate in the Central and Southern Perth basins (Fig. 12; Appendix A). Reduction in leakage to confined systems will result in larger drawdowns if groundwater abstraction from the confined systems continues at current levels.

\subsection{Climate change impacts on the distribution of net recharge}

The distribution of net annual recharge into the water balance components is different under various scenarios in three re- gions (Fig. 13). In the Central Perth Basin over 23 percent of the mean annual recharge, projected to be added to groundwater storage under the wetter climates (historical and wet), is expected to reduce to only 4 percent of net annual recharge under the dry future climate. In the Southern Perth Basin and Peel-Harvey Area the increase in groundwater storage of about 13 percent and zero percent, respectively, of net annual recharge is likely under the historical climate. This is expected to change to loss in groundwater storage equivalent to about 10 to 12 percent of the net annual recharge under the dry future climate.

About 19 to 22 percent and 41 to 58 percent of annual net recharge is projected to discharge to the ocean in the Central and Southern Perth basins, respectively, every year under various scenarios (Fig. 13). In the Peel-Harvey Area discharge is estimated to be less than 5 percent of net annual recharge.

Groundwater discharge to drains is more than 60 percent of net annual recharge in the Peel-Harvey Area because of shallow water tables, and is less likely to change under drier scenarios except under the development scenario where it is expected to reduce to about 37 percent of net annual recharge due to lower water tables caused by additional groundwater pumping. The groundwater discharge to drains is a small portion of the net recharge in the Central Perth Basin (8 percent) and Southern Perth Basin (5 percent) and is expected to reduce under the drier future climates. This is due to smaller areas of shallow water tables compared with the Peel-Harvey Area where most recharge is drained.

The proportion of net annual recharge extracted by pumping is 21 to 34 percent in the Central Perth Basin, larger at 32 to 73 percent in the Peel-Harvey Area, and only 1 to 8 percent in the Southern Perth Basin. Recharge removed by pumping also depends upon annual pumping volumes and sustainable yields which are largest in the Central Perth Basin and lowest in the Peel-Harvey Area. When recharge reduces under the drier climates a greater portion of recharge is consumed by pumping which remains constant between 2008 and 2030 . Net leakage to confined aquifers is a major component of the water balance in both Central (26 to 34 percent) and Southern Perth Basins (33 to 45 percent). Under the drier future climate the percentage of net annual recharge that becomes leakage to confined systems increases due to higher hydraulic gradients as a result of the drawdowns from pumping in the unconfined and confined systems. This does not mean that net leakage volumetrically increases but a greater portion of the reduced recharge leaks to the confined systems.

\subsection{Sensitivity of water balance components to climate change}

The percent change in each water balance component was plotted against percent change in rainfall for three regions of the study area (Fig. 14) to assess the sensitivity of water balance components to climate change. The percent changes are relative to their values under the historical climate. Linear 

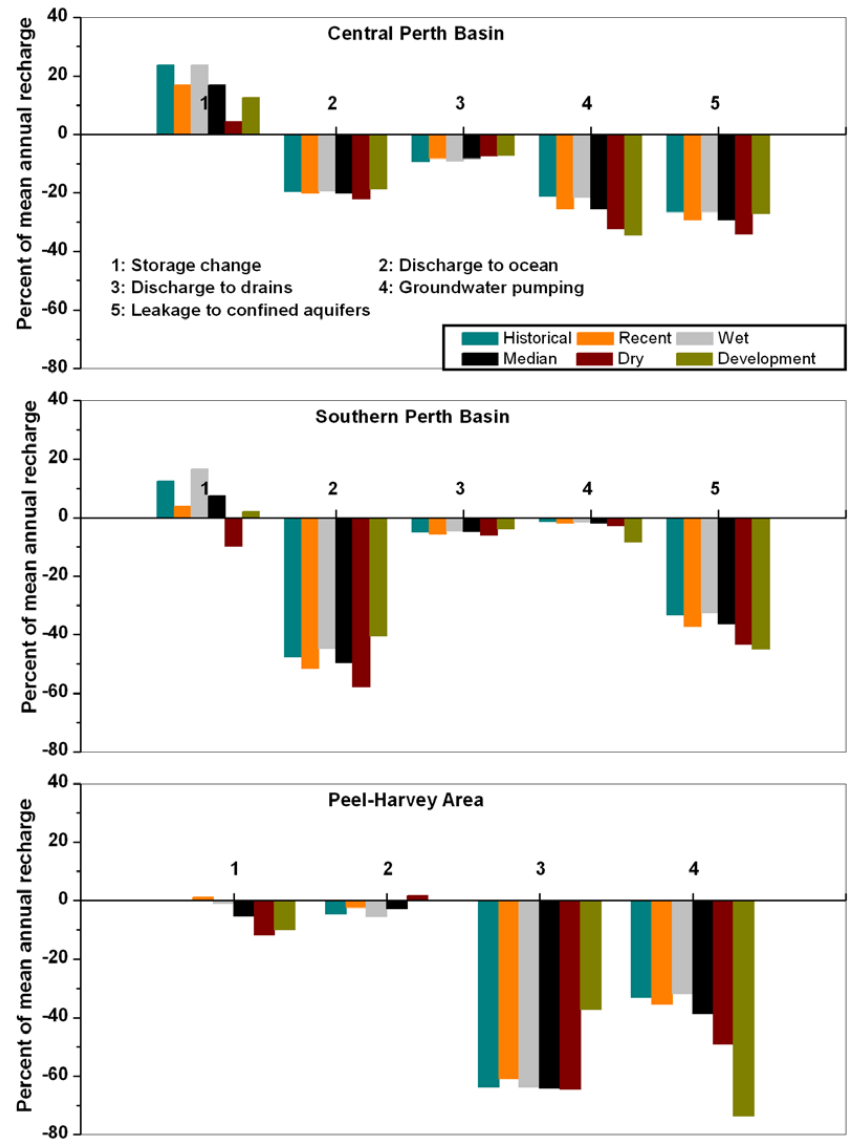

Fig. 13. Water balance components under various scenarios shown as percent of net annual recharge in the Central Perth Basin, PeelHarvey Area and Southern Perth Basin.

trend lines were fitted to show the rate of percent change in each water balance component as a function of percent change in rainfall. An overall average value for percent change in rainfall and water balance components was estimated which was an average of the rates of percent change under four climate scenarios. The rate of percent change indicated by the trend lines may be different to the average of all four scenarios because the trends are indicators and should not be used to estimate the percent change of water balance components.

Figure 14 shows varying sensitivities of water balance components to climate change. Storage is most sensitive to climate and net leakage to confined systems is least sensitive. For every one percent reduction in rainfall the storage reduces by 5 and 8 percent in the Southern and Central Perth basins, respectively. In the Peel-Harvey Area the storage change under the historical climate was zero and percent change under various scenarios relative to that under the historical climate was not estimated but its sensitivity to climate change is similar to the other two regions. The net leakage to confined aquifers is expected to reduce by 1.5 times the percent reduction in rainfall in the Central Perth Basin and 2.5

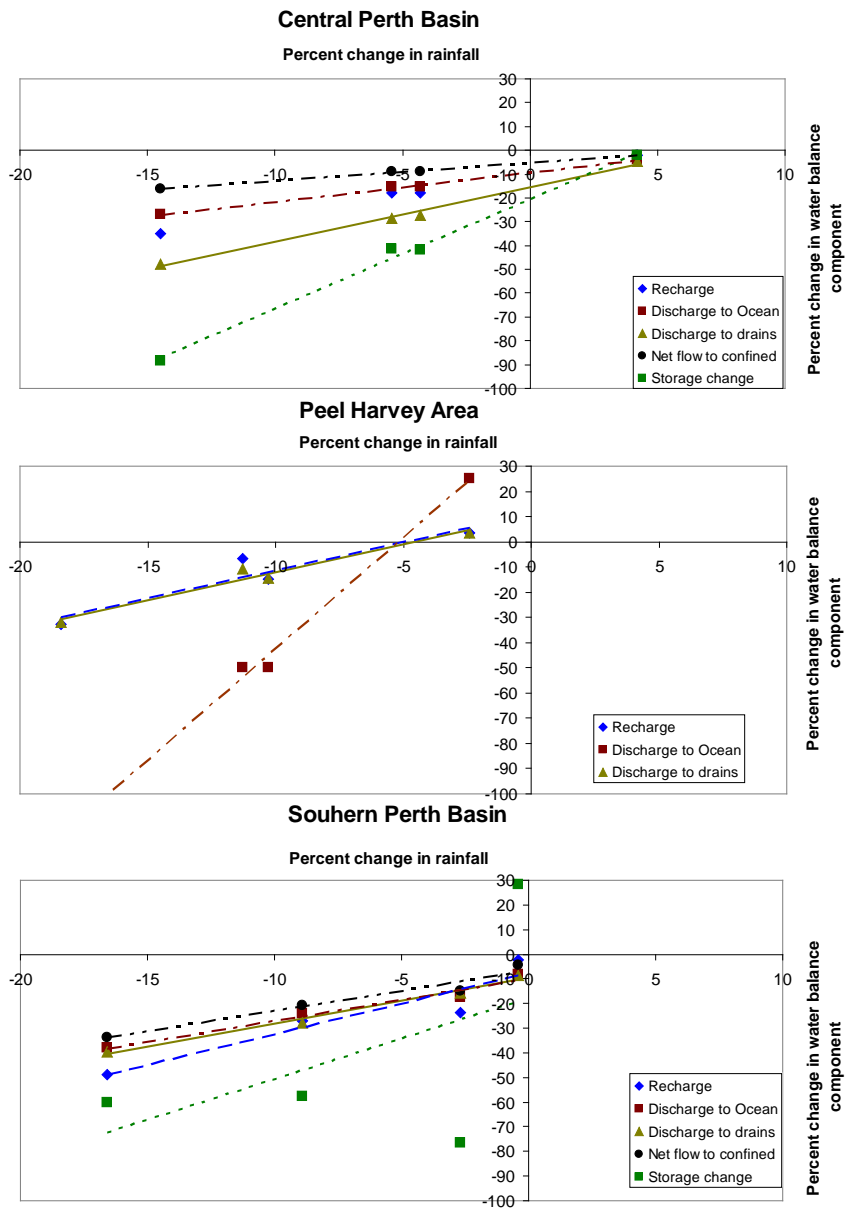

Fig. 14. Relationship between percent change in rainfall and percent change in water balance components relative to the historical climate in the Central Perth Basin, Peel-Harvey Area and Southern Perth Basin.

times the percent decrease in rainfall in the Southern Perth Basin. Low sensitivity of net leakage to confined aquifers is likely due to the hydraulic gradients remaining similar and leakage being controlled by hydraulic conductivities rather than overlying storage.

Recharge is highly sensitive to climate change in the Central and Southern Perth basins where it is projected to reduce by 3.6 percent for every one percent reduction in rainfall. In the Central Perth Basin the rainfall is lower than the Southern Perth Basin but a greater proportion of rainfall becomes recharge due to extensive built-up areas the rainfall from roads and roofs being directed to the underlying aquifers, the predominantly sandy soils and land being used for dryland agriculture. In the Southern Perth Basin a lower portion of annual rainfall becomes recharge due to perennial vegetation and clayey soils. Therefore, reductions in recharge in response to a reduction in rainfall may be similar but due to different processes. Recharge is less sensitive to climate change in the Peel-Harvey Area due to its shallow 
water tables. Decline in water levels is buffered by increases in recharge which would otherwise have been lost through evaporation and drainage.

Groundwater discharge to the ocean is relatively less sensitive to climate change in the Central and Southern Perth basins but very sensitive in the Peel-Harvey Area (Fig. 14). For every one percent reduction in rainfall the ocean discharge reduces by about 3 percent in the Central and Southern Perth basins but by over 6 percent in the Peel-Harvey Area. A change from ocean discharge under the wetter climates (historical and wet) to seawater intrusion under the dry future climate is due to lower water tables. Groundwater discharge to drains is very sensitive to climate change in the Central Perth Basin but less sensitive in the Peel-Harvey Area. For every one percent reduction in rainfall the groundwater discharge to drains reduces by 5.4 percent in the Central Perth Basin, by 3.2 percent in the Southern Perth Basin and by 1.3 percent in the Peel-Harvey Area. There are extensive natural and engineered drainage systems in both the Central Perth Basin and Peel Harvey Area. Those in the PeelHarvey Area are less affected due to shallow water tables over large areas. When shallow water tables decline they accept recharge that would otherwise be rejected and as a result are less sensitive to climate change. In the Central Perth Basin the water tables are relatively deeper and as a result any reduction in recharge results in the water table falling below drain invert levels making them sensitive to climate change. Drainage systems are relatively small in the Southern Perth Basin but are sensitive to climate change due to projected large declines in water tables.

\section{Discussion}

Climate change has already caused a substantial reduction in mean annual rainfall in south-western Australia and a number of other regions during the second half of the 20th century (Ducci and Tranfaglia, 2008; Piao et al., 2010; PMSEIC Independent Working Group, 2007). Almost all GCMs project a further reduction in rainfall in south-western Australia by 2030. Reductions in mean annual rainfall have major implications for groundwater management as it reduces recharge and affects other components of the water balance (Zagonari, 2010). This study and others (Candela et al., 2009; Sandstorm, 1995) show that the projected reduction in recharge is 2 to 4 times the reduction in rainfall. The climate change effect on recharge is likely to impact many regions around the globe and about 18 percent of global population would be affected by a 10 percent reduction in recharge (Döll, 2009). It is likely to impact groundwater storages in many regions even if current pumping rates continues into the future (Green et al., 2011; Loaiciga et al., 2000; Yusoff et al., 2002).

In addition to rainfall the sensitivity of recharge and storage to climate change also depends, on land cover, soil types, water table depth as reported by Crosbie et al. (2010), Mc-
Callum et al. (2010) and Dawes et al. (2012) for Australia and by Jyrkama and Sykes (2007), Liu (2011) and Green et al. (2011) for other regions. Due to clearing in the north-east areas of the Central Perth Basin water tables are projected to rise substantially while they are projected to decline in most other areas. These rising water tables raise mean annual storage over the whole basin. Since most of the natural and engineered drainage exists in areas where water tables are projected to decline, drain discharge is projected to reduce under most future climates. Due to the sandy nature of soils in the Scott Coastal Plain (Southern Perth Basin) and water ponding in areas near the Swan Coastal Plain, water tables in these areas are projected to rise which makes the overall storage change positive although under most of the Blackwood Plateau water tables are projected to decline due to native vegetation and clayey soils.

The depth of the water table also affects groundwater storage and various discharges. Due to shallow water tables under the Peel-Harvey Area some winter recharge was rejected. When water tables decline due to low rainfall more recharge is accommodated and as a result the impact on storage change is low. If water tables decline below the depth that winter rainfall can fill, then groundwater storage will decline, as is the case under most future climate scenarios in other areas. The declining levels in turn reduce drain discharge. In a similar study Goderniaux et al. (2009) projected significant decline in groundwater levels and reduction in river flow rates in the Geer sub-catchment in eastern Belgium due to climate change. The Peel-Harvey Area is topographically flat with low hydraulic gradients towards the ocean. A small decline in water tables is projected to change groundwater flow direction and increase the risk of seawater intrusion under a dry future climate. Giambastiani et al. (2007) similarly reports an increased risk of seawater intrusion, due to climate change, in the unconfined coastal aquifer of Ravenna, Italy.

All climate change studies have some uncertainty in projections (Scibek and Allen, 2006; Weare and Du, 2008; Crosbie et al., 2011) due to uncertainty in GCM predictions, downscaling methods, input parameters and aquifer heterogeneity. Modelling of groundwater systems involves many steps and each introduces some uncertainty. For this study, 15 GCMs were used to derive future climates for south-western Australia and 14 of the 15 project a drier future climate for this region. Therefore, there is less uncertainty in the direction of GCM projections in south-western Australia compared to those regions where GCMs project either a wetter or drier future climate. Daily downscaling techniques used to derive the scaling factors for modification of the historical climate, introduced some uncertainty in the derived future climates. A relatively sophisticated vertical flux model (VFM) used to estimate recharge (instead of its direct input in the groundwater models) was similar to that of Goderniaux et al. (2009) which fully integrates surface- and subsurfaceflows in the saturated and partially saturated zones. The uncertainty in input parameters (land cover, soil and climate) to 
Table A1. Water balance components in the Superficial Aquifer in the Central Perth Basin, Peel-Harvey Area and Southern Perth Basin over the 2008 to 2030 period under various scenarios. The numbers show 23 -yr annual means (mm) under various scenarios.

\begin{tabular}{|c|c|c|c|c|c|c|c|}
\hline Scenario & $\begin{array}{l}\text { Storage } \\
\text { change }\end{array}$ & Recharge & $\begin{array}{c}\text { Discharge } \\
\text { to } \\
\text { ocean }\end{array}$ & $\begin{array}{c}\text { Discharge } \\
\text { to } \\
\text { drains }\end{array}$ & Pumping & $\begin{array}{l}\text { Net flow } \\
\text { to confined } \\
\text { aquifers }\end{array}$ & $\begin{array}{c}\text { Balance } \\
\text { error }\end{array}$ \\
\hline \multicolumn{8}{|c|}{ Central Perth Basin } \\
\hline & \multicolumn{7}{|c|}{$\mathrm{mm} \mathrm{yr}^{-1}$} \\
\hline Historical & 39.3 & 166.7 & -32.8 & -15.5 & -35.1 & -44.0 & 0.0 \\
\hline Recent & 23.0 & 137.2 & -27.8 & -11.1 & -35.1 & -40.1 & 0.0 \\
\hline Wet & 38.4 & 163.0 & -31.6 & -14.8 & -35.1 & -43.2 & 0.0 \\
\hline Median & 22.9 & 137.2 & -27.8 & -11.3 & -35.1 & -40.0 & 0.0 \\
\hline Dry & 4.5 & 108.5 & -24.0 & -8.1 & -35.1 & -36.8 & 0.0 \\
\hline Development & 17.9 & 142.6 & -26.7 & -10.2 & -49.2 & -38.6 & 0.0 \\
\hline \multicolumn{8}{|c|}{ Peel-Harvey Area } \\
\hline Historical & 0.0 & 54.1 & -2.5 & -34.4 & -17.8 & 0.0 & 0.0 \\
\hline Recent & 0.6 & 50.4 & -1.2 & -30.7 & -17.8 & 0.0 & 0.0 \\
\hline Wet & -0.6 & 56.0 & -3.1 & -35.7 & -17.8 & 0.0 & 0.0 \\
\hline Median & -2.5 & 46.1 & -1.2 & -29.5 & -17.8 & 0.0 & 0.0 \\
\hline Dry & -4.3 & 36.3 & 0.6 & -23.4 & -17.8 & 0.0 & 0.0 \\
\hline Development & -6.8 & 67.6 & 0.0 & -25.2 & -49.8 & 0.0 & 0.0 \\
\hline \multicolumn{8}{|c|}{ Southern Perth Basin } \\
\hline Historical & 10.4 & 82.8 & -39.5 & -4.1 & -1.2 & -27.5 & 0.0 \\
\hline Recent & 2.5 & 63.3 & -32.6 & -3.5 & -1.2 & -23.5 & 0.0 \\
\hline Wet & 13.3 & 80.9 & -36.2 & -3.8 & -1.2 & -26.4 & 0.1 \\
\hline Median & 4.4 & 60.4 & -29.9 & -3.0 & -1.2 & -21.9 & 0.0 \\
\hline Dry & -4.2 & 42.2 & -24.4 & -2.5 & -1.2 & -18.3 & 0.0 \\
\hline Development & 1.4 & 69.9 & -28.4 & -2.8 & -5.9 & -31.4 & 0.1 \\
\hline
\end{tabular}

the VFM was reduced by comparison of VFM based recharge estimates with those determined through field studies. However, this could not be done for all land cover types, soils and climate zones in all regions of the study area due to limited availability of field data, so there could still be some uncertainty in these estimates. Two of the three groundwater models used for this assessment have gone through an extensive refinement and recalibration process over time. As a result their reliability, as predictive tools, has improved and uncertainty has reduced. However, the Peel Harvey model used in this study is new and still has to go through the review process. Thus, uncertainty of projections from this model is greater than from the other two models.

\section{Conclusions}

The mean annual rainfall in south-western Australia is projected to further reduce by 7 to 11 percent by 2030 under the median future climate and by 15 to 18 percent under the dry future climate. This will lead to reductions in groundwater recharge of 33 to 49 percent under the dry future climate relative to a continuation of the historical climate of 1975-2007.
The reduction in groundwater recharge is expected to impact all other components of the water balance. The groundwater discharge to the ocean and natural drainages is expected to reduce substantially under the dry future climate. In the PeelHarvey Area in particular there may be an increased risk of seawater intrusion under the dry future climate. The leakage to underlying confined aquifer systems is likely to reduce by 16 to 34 percent in the Central and Southern Perth basins under the dry future climate. The proportion of mean annual recharge being added to groundwater storage is expected to reduce from 23 percent under the wetter (historical and wet future climate) climates to only 4 percent under the dry future climate in the Central Perth Basin. In the Southern Perth Basin and Peel-Harvey Area a loss in groundwater storage is expected under the dry future climate.

Storage changes are most sensitive to climate change while net leakage to confined systems is least sensitive. Recharge is highly sensitive to climate change in the Central and Southern Perth basins and less sensitive in the PeelHarvey Area. Groundwater discharge to the ocean is very sensitive to climate change in the Peel-Harvey Area but less sensitive in the Central and Southern Perth basins. Groundwater discharge to drains is highly sensitive to climate 
change in the Central Perth Basin and less sensitive in the Peel-Harvey Area. The model estimates of climate change impacts on the water balance are important data for future water resources management in the region.

Acknowledgements. This study was a part of the project funded by the Australian Government Department of Environment, Water, Heritage and the Arts. The authors thank for valuable contributions from Chris O'Boy, Binh Anson, Phil Commander, Cahit Yesertener, Jayath de Silva and Jasmine Rutherford of the Department of Water, Western Australia. Useful input and valuable contribution from Mike Canci and Chengchao $\mathrm{Xu}$ of the Water Corporation, Western Australia is acknowledged. The authors thank Wen Yu, Andrew Brooker, Amandine Bou and Andrew McTaggart of URS Australia for developing the PHRAMS and Neil Milligan of the Cymod Systems for linking VFM with groundwater models and their calibration update. Help from CSIRO editing team and constructive comments from internal and external reviewers are greatly appreciated.

Edited by: K. Hinsby

\section{References}

Aguilera, H. and Murillo, J. M.: The effect of possible climate change on natural groundwater recharge based on a simple model: a study of four karstic aquifers in south east Spain, Environ. Geol., 57, 963-974, 2009.

Aldous, A., Fitzsimons, J., Richter, B., and Bach, L.: Droughts, floods and freshwater ecosystems: evaluating climate change impacts and developing adaptation strategies, Mar. Freshwater Res., 6, 223-231, 2011.

Ali, R., Emelyanova, I., Dawes, W., Hodgson, G., McFarlane, D. J., Varma, S., and Turner, J.: Groundwater methods used in the south-west Western Australia Sustainable Yields project, A report to the Australian Government from the CSIRO South-West Western Australia Sustainable Yields Project. CSIRO Water for a Healthy Country National Research Flagship, Australia, 117 pp., available at: http: //www.clw.csiro.au/publications/waterforahealthycountry/ swsy/pdf/SWSY-TR-groundwater-methods.pdf (last access: 21 September 2012), 2010.

Ali, R., McFarlane, D., Varma, S., Dawes, W., Emelyanova, I., Hodgson, G., and Charles, S.: Potential climate change impacts on groundwater resources of south-western Australia, J. Hydrol., 475, 456-472, doi:10.1016/j.jhydrol.2012.04.043, 2012

Baddock, L.: South West Yarragadee Hydrogeological Investigations and Evaluation, Southern Perth Basin, Water Corporation Perth, Western Australia, 2005.

Barr, A. D., Xu, C., and Silberstein, R.: Vertical Flux Model Manager for the Perth Regional Aquifer Model System - description and use manual for Water Corporation by CSIRO Land and Water, 2003.

Barron, O., Silberstein, R., Ali, R., Donohue, R., McFarlane, D. J., Davies, P., Hodgson, G., Smart, N., and Donn, M.: Climate change effects on water-dependent ecosystems in south-western Australia, J. Hydrol., 434-435, 95-109, doi:10.1016/j.jhydrol.2012.02.028, 2012.
Barthel, R., Reichenau, T. G., Muerth, M., Heinzeller, C., Schneider, K., Hennicker, R., and Mauser, W.: Global change impacts on groundwater in Southern Germany-Part 1: Natural aspects, Grundwasser, 16, 259-268, doi:10.1007/s00767-0110180-y, 2011.

Batelaan, O. and De Smedt. F.: WetSpass: a flexible, GIS based, distributed recharge methodology for regional groundwater modeling, in: Impact of human activity on groundwater dynamics, edited by: Gehrels, H., Peters, J., Hoehn, E., Jensen, K., Leibundgut, C., Griffioen, J., Webb, B., and Zaadnoordijk, W. J., IAHS Publication, 269, IAHS, Wallingford, UK, 11-17, 2001.

Candela, L., von Igel, W., Javier Elorza, F., and Aronica, G.: Impact assessment of combined climate and management scenarios on groundwater resources and associated wetland (Majorca, Spain), J. Hydrol., 376, 510-527, 2009.

Charles, S. P., Silberstein, R., Teng, J., Fu, G., Hodgson, G., Gabrovsek, C., Crute, J., Chiew, F. H. S., Smith, I. N., Kirono, D. C. G., Bathols, J. M., Li, L. T., Donohue, R. J., Marvanek, S P., McVicar T. R., van Niel, T. G. and Cai, W.: Climate analyses for the South-West Western Australia Sustainable Yields Project. A report to the Australian Government from the CSIRO SouthWest Western Australia Sustainable Yields Project, CSIRO Water for a Healthy Country National Research Flagship, Australia, 83 pp., 2010.

Chiew, F. H. S., Teng, J., Vaze, J., Post, D. A., Perraud, J. M., Kirono. D. G. C., and Viney, N. R.: Estimating climate change impact on runoff across southeast Australia: Method, results, and implications of the modeling method, Water Resour. Res., 45, W10414, doi:10.1029/2008WR007338, 2009.

Christensen, J. H., Hewitson, B., Busuioc, A., Chen, A., Gao, X., Held, I., Jones, R., Kolli, R. K., Kwon, W. T., Laprise, R., Magana, R. V., Mearns, L., Menendez, C. G., Raisanen, J., Rinke, A., Sarr, A., and Whetton, P.: Regional climate projections, in: Climate Change 2007: The physical Science basis, Contribution of Working Group I to the Fourth Assessment Report of the Intergovernmental panel on Climate Change, edited by: Solomon, S., Qin, D., Manning, M., Chen, Z., Marquis, M., Averyt, K. B., Tignor, M., and Millar, H. L., Cambridge University Press, Cambridge, UK and NY, USA, 2007.

Crosbie, R., McCallum, J., Walker, G. R., and Chiew, F. H. S.: Modelling climate-change impacts on groundwater recharge in the Murray-Darling Basin, Australia, Hydrogeol. J., 18, 1639-1656, 2010.

Crosbie, R. S., Dawes, W. R., Charles, S. P., Mpelasoka, F. S., Aryal, S., Barron, O., and Summerell, G. K.: Differences in future recharge estimates due to GCMs, downscaling methods and hydrological models, Geophys. Res. Lett., 38, 111406, doi:10.1029/2011GL047657, 2011.

CSIRO: Water Availability in the Murray-Darling Basin, A report to the Australian Government from the CSIRO Murray-Darling Basin Sustainable Yields Project, 67 pp., available at: http: //www.csiro.au/files/files/pna0.pdf (last access: 28 November 2012), 2008.

CSIRO: Groundwater yields in south-west Western Australia, A report to the Australian Government from the CSIRO SouthWest Western Australia Sustainable Yields Project, CSIRO Water for a healthy Country Flagship, 330 pp., available at: http: //www.clw.csiro.au/publications/waterforahealthycountry/ swsy/pdf/SWSY-Main-Report-Groundwater.pdf

(last 
access: 28 November 2012), 2009.

Cymod Systems Pty Ltd: Calibration of the Coupled Perth Regional Aquifer Model PRAMS 3.2, Report to the Department of Water, Western Australia from Cymod Systems, 33 pp., 2009.

Davidson, W.: Hydrogeology and groundwater resources of the Perth region, Western Australia, Bulletin 142 Geological Survey of Western Australia, 1995.

Davidson, W. A. and Yu, X.: Perth regional aquifer modelling system (PRAMS) model development: Hydrogeology and groundwater modelling, Hydrogeological record series, Report No. HG 20, Department of Water, Perth Western Australia, 2008.

Dawes, W., Ali, R., Varma, S., Emelyanova, I., Hodgson, G., and McFarlane, D.: Modelling the effects of climate and land cover change on groundwater recharge in south-west Western Australia, Hydrol. Earth Syst. Sci., 16, 2709-2722, doi:10.5194/hess-16-2709-2012, 2012.

Döll, P.: Vulnerability to the impact of climate change on renewable groundwater resources: a global-scale assessment, Environ. Res. Lett., 4, 035006, doi:10.1088/1748-9326/4/3/035006, 2009.

DoW (Department of Water): South West Water Resources - A Review of Future Trends, Department of Water, Perth, Western Australia, 2007.

DoW: Western Australia's achievements in implementing the National Water Initiative, Progress report, Department of Water, Perth, Western Australia, 2008a.

DoW: South-west groundwater areas water management plan - allocation, draft for comment, Department of Water, Perth, Western Australia, 2008b.

Ducci, D. and Tranfaglia, G.: Effects of climate change on groundwater resources in Campania (southern Italy), in: Climate Change and Groundwater, edited by: Dragoni, W. and Sukhija, B. S., Geological Society, London, Special Publication, 25-38, 2008.

Giambastiani, B. M. S., Antonellini, M., Oude Essink, G. H. P., and Stuurman, R. J.: Saltwater intrusion in the unconfined coastal aquifer of Ravanna (Italy): A numerical model, J. Hydrol., 340, 91-104, 2007.

Goderniaux, P., Brouyere, S., Fowler, H. J., Blenkinsop, S., Therrien, R., Orban, P., and Dassargues, A.: Large scale surfacesubsurface hydrological model to assess climate change impacts on groundwater reserves, J. Hydrol., 373, 122-138, 2009.

Goderniaux, P., Brouyere, S., Blenkinsop, S., Burton, A., Fowler, H. J., Orban, P., and Dassargues, A.: Modeling climate change impacts on groundwater resources using transient stochastic climatic scenarios, Water Resour. Res., 47, W12516, doi:10.1029/2010wr010082, 2011.

Green, T. R., Taniguchi, M., Kooi, H., Gurdak, J. J., Allen, D. M., Hiscock, K. M., Treidel, H., and Aureli, A.: Beneath the surface of global change: Impacts of climate change on groundwater, J. Hydrol., 405, 532-560, 2011.

Herrera-Pantoja, M. and Hiscock, K. M.: The effect of climate change on potential groundwater recharge in Great Britain, Hydrol. Process., 22, 73-86, 2008.

Hinsby, K., Markager, S., Kronvang, B., Windolf, J., Sonnenborg, T. O., and Thorling, L.: Threshold values and management options for nutrients in a catchment of a temperate estuary with poor ecological status, Hydrol. Earth Syst. Sci., 16, 2663-2683, doi:10.5194/hess-16-2663-2012, 2012.
Holman, I. P.: Climate change impacts on groundwater rechargeuncertainty, shortcomings, and the way forward, Hydrogeol. J., 14, 637-647, doi:10.1007/s10040-005-0467-0, 2006.

Intergovernmental Panel on Climate Change (IPCC): Climate Change 2007: The Physical Basis, Contributions of Working Group I to the Fourth Assessment Report of the Intergovernmental Panel on Climate Change, edited by: Solomon, S., Qin, D., Manning, M., Chen, Z., Marquis, M., Averyt, K. B., Tignor, M., and Miller, H. L., Cambridge University Press, 1007 pp., available at: http://www.ipcc.ch/pdf/assessment-report/ar4/wg1/ ar4_wg1_full_report.pdf (last access: 28 November 2012), Cambridge, U. K. Mitchell, T. D. (2003), Pattern scaling, Clim. Change, 60, 217-242, doi:10.1023/A:1026035305597, 2007.

Issar, A. S.: A tale of two cities in ancient canaan: how the groundwater storage capacity of Arad and Jericho decided their history, in: Climate Change and Groundwater, edited by: Dragoni, W. and Sukhija, B. S., Geological Society, London, Special Publication, 137-143, 2008.

Jeppesen, E., Kronvang, B., Meerhoff, M., Søndergaard, M., Hansen, K. H., Andersen, H. E., Lauridsen, T. L., Liboriussen, L., Beklioglu, M., Ozen, A., and Olesen, J. E.: Climate change effects on runoff, catchment phosphorus loading and lake ecological state, and potential adaptations, J. Environ. Qual., 38, 19301941, 2009.

Jiang, T., Chen, Y. D., Xu, C., Chen, X., Chen, X., and Singh, V. P.: Comparison of hydrological impacts of climate change simulated by six hydrological models in the Dongjiang Basin, South China, J. Hydrol., 336, 316-333, 2007.

Jie, Z., van Heyden, J., Bendel, D., and Barthel, R.: Combination of soil-water balance models and water-table fluctuation methods for evaluation and improvement of groundwater recharge calculations, Hydrogeol. J., 19, 1487-1502, doi:10.1007/s10040-0110772-8, 2011.

Jyrkama, M. I. and Sykes, J. F.: The impact of climate change on spatially varying groundwater recharge in the grand river watershed (Ontario), J. Hydrol., 338, 237-250, 2007.

Lasch, P., Linder, M., Erhard, M., Suckow, F., and Wenzel, A.: Regional impact assessment on forest structure and functions under climate change-the Brandenburg case study, For. Ecol. Manage., 162, 73-86, 2002.

Liu, Hui-Hui: Impact of climate change on groundwater recharge in dry areas: An ecohydrology approach, J. Hydrol., 407, 175-183, doi:10.1016/j.jhydrol.2011.07.024, 2011.

Loaiciga, H. A., Maidment, D. R., and Valdes, J. B.: Climate-change impacts in a regional karst aquifer, Texas, USA, J. Hydrol., 227, 173-194, 2000.

Loaiciga, H. A., Valdes, J. B., Vogel, R., Garveym, J., and Schwarz, H.: Global warming and the hydrologic cycle, J. Hydrol., 174, 83-127, 1996.

Marshall, E. and Randhir, T.: Effect of climate change on watershed system: A regional analysis, Climate Change, 89, 263-280, doi:10.1007/s10584-007-9389-2, 2007.

McCallum, J. L., Crosbie, R. S., Walker, G. R., and Dawes, W. R.: Impacts of climate change on groundwater in Australia: a sensitivity analysis of recharge, Hydrogeol. J., 18, 1625-1638, 2010.

McCarthy, J. J., Canziani, O. F., Leary, N. A., Dokken, D. J., and White, K. S. (Eds): Climate Change 2001: Impacts, Adaptation, and Vulnerability, Contribution of Working Group II to the Third Assessment Report of the Intergovernmental Panel on Climate 
Change, Cambridge University Press: Cambridge, 2001.

McDonald, M. and Harbaugh, A.: User's documentation for MODFLOW-96, an update to the US GeologicaL Survey Modular finite-difference Groundwater Flow Model, US Geological Survey, Open-File Report 96-485, 1996.

Mitchell, T. D.: Pattern scaling: An examination of the Accuracy of the technique for Describing Future Climates, Climatic Change, 60, 217-242, doi:10.1023/A:1026035305597, 2003.

Morton, F. I.: Operational estimates of areal evapotranspiration and their significance to the science and practice of hydrology, J. Hydrol., 66, 1-76, 1983.

Mpelasoka, F. S. and Chiew, F. H. S.: Influence of rainfall scenario construction methods on runoff projections, J. Hydrometeorol., 10, 1168-1183, 2009.

Ng, G.-H. C., McLaughlin, D., Entekhabi, D., and Scanlon, B. R.: Probabilistic analysis of the effects of climate change on groundwater recharge, Water Resour. Res., 46, W07502, doi:10.1029/2009wr007904, 2010.

Olesen, J. E., Carter, T. R., Diaz-Ambrona, C. H., Fronzek, S., Heidmann, T., Hickler, T., Holt, T., Minguez, M. I., Morales, P., Palutikof, J. P., Quemada, M., Ruiz-Ramos, M., Rubaek, G. H., Sau, F., Smith, B., and Sykes, M. T.: Uncertainties in projected impacts of climate change on European agriculture and terrestrial ecosystems based on scenarios from regional climate models, Climatic Change, 81, 123-143, 2007.

Piao, S., Ciais, P., Huang, Y., Shen, Z., Peng, S., Li, J., Zhou, L., Liu, H., Ma, Y., Ding, Y., Friedlingstein, P., Liu, C., Tan, K., Yu, Y., Zhang, T., and Fang, J.: The impacts of climate change on water resources and agriculture in China, Nature, 467, 43-51, doi:10.1038/nature09364, 2010.

Pirani, A.: WCRP coupled intercomparison project - Phase 5 - CMIP5., International CLIVAR project office, National Oceanography Centre, Southampton, UK, CLIVAR Exchanges No. 56, Vol. 16, No. 2, 2011.

PMSEIC Independent Working Group: Climate Change in Australia: Regional Impacts and Adaptation - Managing the Risk for Australia, Report Prepared for the Prime Minister's Science, Engineering and Innovation, Council, Canberra, 57 pp., 2007.

Polemio, M. and Casarano, D.: Climate change, drought and groundwater availability in southern Italy, in: Climate Change and Groundwater, edited by: Dragoni, W. and Sukhija, B. S., Geological Society, London, Special Publication, 39-51, 2008.

Post, D. A., Chiew, F. H. S., Teng, J., Viney, N. R., Ling, F. L. N., Harrington, G., Crosbie, R. S., Graham, B., Marvanek, S., and McLoughlin, R.: A robust methodology for conducting largescale assessments of current and future water availability and use: A case study in Tasmania, Australia, J. Hydrol., 412, 233-245, doi:10.1016/j.jhydrol.2011.02.011, 2011.

Sandstrom, K.: Modelling the effects of rainfall variability on groundwater recharge in semi-arid Tanzania, Nord. Hydrol., 26, 313-330, 1995.

Sanford, W.: Recharge and groundwater models: an overview, Hydrogeol. J., 10, 110-120, doi:10.1007/s10040-001-0173-5, 2002.

Scibek, J. and Allen, D. M.: Modeled impacts of predicted climate change on recharge and groundwater levels, Water Resour. Res., 42, 1-18, doi:10.1029/2005WR004742, 2006.

Sinha, U. K. and Navada, S. V.: Application of isotope techniques in groundwater recharge studies in arid western Rajasthan, India: some case studies, in: Climate Change and Groundwater, edited by: Dragoni, W. and Sukhija, B. S., Geological Society, London, Special Publication, 121-135, 2008.

Sonnenborg, T. O., Hinsby, K., van Roosmalen, L., and Stisen, S.: Assessment of climate change impacts on the quantity and quality of a coastal catchment using a coupled groundwater-surface water model, Climatic Change, 113, 1025-1048, 2012.

Strategen: South West Yarragadee-Blackwood Groundwater Area Water Study Report, Report prepared for Water and Rivers Commission, Western Australia, 2004.

Strategen: Hydrogeology of the Southern Perth Basin, South West Yarragadee Water Supply Development, Information series Report No. 1, prepared for Water Corporation, Western Australia, 2005.

Sun, H.: Construction, calibration and application of the South West Yarragadee Aquifer Model V2.0, Water Corporation, 2005.

Taylor, K. E., Stouffer, R. J., and Meehl, G. A.: An overview of CMIP5 and the experimental design, B. Am. Meteorol. Soc., 93, 485-498, 2012.

UNEP: Addressing the leadership challenges of climate change; United nations headquarters, New York, Fact Sheet, 15 pp., 2007.

URS: Peel-Harvey Coastal Groundwater Model WA, Conceptual Model, Prepared for CSIRO, Perth, Westerm Australia, 2009a.

URS: Peel-Harvey Coastal Groundwater Model WA, Model construction and calibration, Prepared for CSIRO, Perth, Westerm Australia, 2009b.

van Gool, D. and Runge, W.: Coastal land and Groundwater for Horticulture from Gingin to Augusta (second edition), Resource Management Technical Report No. 181, Department of Agriculture, Western Australia, 1999.

van Roosmalen, L., Christensen, B. S. B., and Sonnenborg, T. O.: Regional differences in climate change impacts on groundwater and stream discharge in Denmark, Vadose Zone J., 6, 554-571, doi:10.2136/vzj2006.0093, 2007.

van Roosmalen, L., Sonnenborg, T. O., and Jensen, K. H.: Impact of climate and land use change on the hydrology of a largescale agricultural catchment, Water Resour. Res., 45, W00A15, doi:10.1029/2007wr006760, 2009.

Weare, B. C. and Du, H.: Modelling regional climate changes: influence of recent global warming and irrigation in California, Int. J. Climatol., 28, 1201-1212, doi:10.1002/joc.1622, 2008

Woldeamlak, S. T., Batelaan, O., and De Smedt, F.: Effects of climate change on the groundwater system in the Grote-Nete catchment, Belgium, Hydrogeol. J., 15, 891-901, 2007.

Yusoff, I., Hiscock, K. M. and Conway, D.: Simulation of the impacts of climate change on groundwater resources in Eastern England, in: Sustainable Groundwater Development, edited by: Hiscock, K. M., Rivett, M. O., and Davison, R. M., Geological Survey of London, London, 325-344, 2002.

Zagonari, F.: Sustainable, just, equal, and optimal groundwater management strategies to cope with climate change: Insights from Brazil, Water Resour. Manage., 24, 3731-3756, doi:10.1007/s11269-010-9630-z, 2010.

Zhang, L. and Dawes, W.: WAVES - An integrated energy and water balance model, CSIRO Land and Water Technical Report No 31/98, Perth, Australia, 1998. 